\title{
Pamukkale Üniversitesi Öğrencilerinin Yaşam Kalitesi, Örgütsel İmaj ve Özdeşleşme Düzeyleri Arasındaki İlişkilerin İncelenmesi ${ }^{1}$
}

\author{
Uğur SÖNMEZOĞLU², Hüseyin GÖKÇE ${ }^{3}$ ve Gizem KARAKAŞ ${ }^{4}$
}

\section{$\ddot{\mathrm{O} z}$}

Araştırmada, Pamukkale Üniversitesi (PAÜ) öğrencilerinin üniversite yaşam kalitesi, örgütsel imaj ve özdeşleşme düzeyleri arasındaki ilişskilerin incelenmesi amaçlanmıştır. Çalışma tarama araştırmaları kapsamında gerçekleştirilmiştir. PAÜ’ye bağlı birimlerde öğrenim gören 583 kadın ve 923 erkek toplam 1506 öğrenci kümelere göre örnekleme tekniğiyle belirlenerek örnekleme dâhil olmuştur. Çalışmada kişisel bilgi formu, Üniversite Yaşam Kalitesi Ölçeği, Üniversite İmaj Algisı Ölçeği, Örgütsel Özdeşleşme Ölçeği kullanılmıştır. Verilere bağımsız gruplarda t-testi, korelasyon ve regresyon analizleri yapılmıştır. Kadın öğrencilerin üniversite yaşam kalite düzeyleri, imaj algıları ve özdeşleşme düzeyleri erkek öğrencilerden yüksek bulunmuştur. Spor yapan öğrencilerin üniversite imaj algılarının yapmayanlara göre yüksek olduğu; özdeşleşme düzeyinde ise anlamlı bir farkl1lık yaratmadığ1 görülmüştür. Öğretim eleman1-öğrenci iletişimi, sosyal olanak, öğrenciöğrenci iletişimi ve gelecek alt boyutlarında spor yapanların yaşam kalitesi daha yüksek bulunmuştur. Ölçeklerin tüm alt boyutlarında orta ve zayıf düzeyde pozitif anlamlı bir ilişki tespit edilirken; yaşam kalitesinin yalnızca kimlik alt boyutunun, imaj algısının tüm alt boyutlarıyla ve özdeşleşme ölçeğiyle aralarında zayıf düzeyde negatif anlamlı bir ilişki tespit edilmiştir. Yaşam kalitesi, üniversite imajını ve özdeşleşme düzeyini etkilerken; imaj algısının ayrıca özdeşleşme düzeyi üzerinde de etkisi olduğu görülmüştür. Sonuç olarak, PAÜ yaşam kalitesinin öğrencilerin üniversite imajını algılama biçimlerini ve özdeşleşme düzeylerini pozitif yönde etkilediği görülmüştür.

Anahtar Kelimeler: Pamukkale Üniversitesi, Yaşam kalitesi, Örgütsel imaj, Özdeşleşme

\section{A Study of the Relationship between Pamukkale University Students' Quality of Life, Organizational Image and Level of Identification}

\section{Abstract}

In this study, it was aimed to investigate the relationship between the quality of life of university, organizational image and identification degrees of university students. The study was conducted within the scope of survey research. In this study, 583 female and 923 male students in various units affiliated to Pamukkale University were included in the sampling by cluster sampling technique. The personal information, Quality of Life in University Scale, Perceived Organizational Image Scale and Organizational Identification Scale was utilized for the study. Independent samples t-test, correlation and regression analyzes were performed on the obtained data. Female students' quality of life, image perceptions and identification levels were higher than male students. It is found that Students who do sports have higher perceptions of university image than those who do not; It was observed that there was no significant difference in the level of identification. The quality of life of the athlete was higher in the lecturer-student communication, social opportunities, student-student communication and future sub-dimension. In all sub-dimension of the scales, a positive significant relationship is found in moderate and weak levels. A negatively significant relationship is found between only the identity sub-dimension of quality of life, with all sub dimensions of image perception and identification sub-dimension. According to the results of regression analysis, the quality of life affects the image of the university and the level of identification. Image perception has also been shown to have an effect on the level of identification. As a result, it was observed that the quality of life of PAU affects positively students' perception of university image and the level of identification.

Key Words: Pamukkale University, Quality of life, Organizational image, Organizational identification

\section{Atıf İçin / Please Cite As:}

Sönmezoğlu, U., Gökçe, H. ve Karakaş G. (2020). Pamukkale Üniversitesi öğrencilerinin yaşam kalitesi, örgütsel imaj ve özdeşleşme düzeyleri arasındaki ilişkilerin incelenmesi. Manas Sosyal Araştırmalar Dergisi, 9(3), 18031819.

Geliş Tarihi / Received Date: 03.04.2019

Kabul Tarihi / Accepted Date: 17.04.2020

\footnotetext{
${ }^{1}$ Bu çalışma 15-18 Kasım 2017 tarihleri arasında Antalya'da düzenlenen 15. Uluslararası Spor Bilimleri Kongresi’nde sözel bildiri olarak sunulmuş ve ilgili kongrenin özet kitabında yayınlanmıştır.

2 Doç. Dr. - Pamukkale Üniversitesi Spor Bilimleri Fakültesi, usonmezoglu@pau.edu.tr - ORCID: 0000-0002-6313-1329

${ }^{3}$ Dr. Öğr. Üyesi - Pamukkale Üniversitesi Spor Bilimleri Fakültesi, hgokce@pau.edu.tr - ORCID: 0000-0001-9250-0317

${ }^{4}$ Dr. Öğr. Üyesi - Sakarya Uygulamalı Bilimler Üniversitesi Spor Bilimleri Fakültesi, gdogduay@subu.edu.tr

ORCID: 0000-0002-6317-6367
} 


\section{Giriş}

Eğitim bireylerin yaşamı boyunca süren ve ülkenin geleceğini şekillendiren önemli bir konudur. Dolayısıyla kurumlarca verilen eğitimin kalitesi son derece önemlidir (Eriş ve Anıl, 2015, s. 1). Eğitimin üst basamağında yer alan 196 yükseköğretim kurumunda, Türkiye 2017 verilerine göre, 2.555 .926 kişi ön lisans, 4.071 .579 kişi lisans, 480.215 kişi yüksek lisans, 91.267 kişi doktora eğitimine devam etmektedir. Her yıl 1,5 milyondan fazla öğrenci üniversite sınavı için sınava girmekte ve üniversite sınavından almış oldukları puanları ile kendi belirlemiş oldukları ölçütleri doğrultusunda tercihte bulunmaktadır. Bu ölçütlerden başlıcaları; eğitimin kalitesi, yabancı dil eğitimi, burs imkânı ve üniversitenin bulunduğu şehir gibi faktörlerdir (Çatı vd., 2016, s. 164). Bir üniversitenin eğitim olanakları ile fiziksel ve sosyal imkânları ne kadar çeşitli ve zengin içerikli olursa öğrencilerin üniversite ortamından alacakları haz da o derece yüksek olacaktır. Öğrencilerin bulunduğu ortamdan aldıkları haz; onların akademik başarılarını, yaşam doyumlarını, sosyal ilişkilerini ve dolaylı olarak gelecek hayatlarını olumlu etkilemektedir (Moller, 1996). Üniversitelerin sunduğu eğitim ve olanakların kişilerin yaşam kalitesini yükseltmesine de yardımcı olduğu düşünülmektedir.

Öğrencilerin yaşam kalitesinin artırılmasının, eğitimde çok daha iyi sonuçlar alınmasına katkı sağladığ1 bilinmektedir (Eriş ve Anıl, 2015, s.1). Öğrenciler tercihte bulunurken, üniversiteler de başarıll öğrenciler tarafindan tercih edilmek için öğrencilerin rahatça yaşayabileceği, üniversitede olmaktan mutlu olacakları alanları oluşturmak zorundadır. $\mathrm{Bu}$ yüzden üniversiteler tercihlerde öne çıkmak ve öğrencilerinin başarılarını arttırmada rekabet içerisine girmektedir. Rekabetin yoğun olduğu bu dönemde finansal sınırlamalar, nüfus piramidindeki değişimler, müfredat ve eğitim sistemlerinin yeniden şekillendirilmesi gibi durumlar eğitim kurumlarının toplumun ihtiyaç ve ilgisi doğrultusunda değişmesi ve yenilenmesini gerekli kılmaktadır (Karacabey vd., 2016, s. 470). Bu noktada üniversitelerin örgütsel imajlarını da sürekli olarak kamuoyu önünde olumlu şekilde güçlendirmeleri gerekmektedir.

Örgütsel imaj, kurumun etkilediği bireylerin (çalışanlar, müşteriler, öğrenciler, öğretim elemanlar vb) zihninde gelişen örgütle ilgili yargıları ve değerlendirmeleridir (Wilson, 2001). Bir başka deyişle diğer bireylerin örgütü nasıl algıladıklarıdır (Dutton ve Dukerich, 1991, s. 518). Örgütsel imajı güçlü kurumlar ve kuruluşlar kaliteli, güvenilir, saygın ve orijinal gibi sıfatlarla nitelendirilmektedir (Polat, 2009, s. 250).

Bir gruba ait olma duygusu olan sosyal özdeşleşmenin kurumlardaki hali olan örgütsel özdeşleşme kavramının örgüt ve birey açısından fayda içerdiği düşünülmektedir. Örgüte ait olma birlikte hareket etme (Ashforth ve Mael, 1989, s. 22) olarak tanımlanan örgütsel özdeşleşmenin derinliğini; bireyin benliğindeki alg1s1 belirlemektedir (Karabey ve İşcan, 2007, s. 231). Birey benliğinde algiladığ1 yüksek derecede özdeşleşme duygusu, bireyin daha çok örgütün bir parçası gibi hissetmesine, örgütün hedeflerini daha çok benimsemesine ve performansını olumlu etkileyeceğine olan inanç, günümüzde örgütsel özdeşleşme çalışmalarının asıl amacını oluşturmaktadır. Örgütle özdeşlemeyi etkileyen pek çok unsur bulunmaktadır. $\mathrm{Bu}$ unsurlardan biri de etkin örgütsel iletişimdir. Etkin örgütsel iletişim ile üyenin örgütle özdeşleşmesi güçlendirilebilir. Çünkü iletişim yoluyla, bireylere örgütün değerleri, özellikleri, hedefleri aktar1lır. Günümüzde örgütler bünyesinde bulunan kişilerin örgütlerini sevmelerini ve sadakat duygusuna sahip olma gibi bir takım duyguların ötesine geçmelerini beklemekte; örgütü bireysel kimlikleri ile özdeşleştirecek ölçüde benimsemelerini istemektedir. Levinson (1965) bu durumu, eskiden insanların, kendilerini isimleriyle ya da yaptıkları işle özdeşleştirirken, günümüzde çalışıłkları örgütlerle tanımladıklarını ifade ederek açıklamaya çalışır. Örgüt üyeliğini çalışanların benliklerinin önemli bir parçası haline getirmek ve onların kendilerini örgüte üye olmakla tanımlarken gurur duymalarını sağlamak, bugün içinde bulunduğumuz koşullarda, uzun vadeli başarılar kazanmada anahtar nitelikte bir role sahiptir (İşçan, 2006, s. 177).

Üniversitelerin bir üyesi olan öğrencilerin kendilerini üniversitenin bir parçası olarak hissetmesinde üniversitenin kendilerine sağladığı hizmetler ve koşulların etkisinin önemli bir etken olduğu bir gerçektir. Bu doğrultuda bu araştırmada, Pamukkale Üniversitesi öğrencilerinin üniversite yaşam kalitesi, örgütsel imaj ve özdeşleşme düzeyleri arasındaki ilişkilerin incelenmesi amaçlanmışıı. Araştırmanın alt amaçlarında öğrencilerin üniversite yaşam kalitesi, örgütsel imaj ve özdeşleşme düzeylerinin cinsiyet, her hangi bir topluluğa üye olma, spor yapıp yapmama durumuna göre farklılaşma durumları ve üniversite imajının özdeşleme düzeyi ve üniversite yaşam kalitesi üzerine etkisinin incelenmesi amaçlanmıştır. 


\section{Yöntem}

\section{Araştırma Modeli}

Çalışma (anlık) tarama araştırmaları kapsamında gerçekleștirilmiştir. Büyüköztürk vd. (2019, s.184) göre, büyük bir topluluğun bir konu ile ilgili görüşlerinin ya da özelliklerinin belli bir zamanda var olduğu şekliyle betimlendiği araştırmalardır. Bu tür araştırmalar diğer araştırmalara göre görece daha büyük örnekleme sahip olurlar.

\section{Evren - Örneklem}

Çalışmada, Pamukkale Üniversitesi 2016-2017 eğitim öğretim yllı bahar döneminde 16 fakülte, 12 meslek yüksekokulu ve 3 yüksekokulda öğrenim gören 55.800 öğrenci araştırmanın evrenini oluşturmaktadır. Örneklemin belirlenmesinde kümelere göre örnekleme tekniği kullanılmışır. Örnekleme sunulan 2500 adet ölçekten 2100 'ü geriye dönüş sağlamış ve 594 adet hatalı/eksik ölçek tespit edilmiştir. Nihai olarak 583 kadın (\%37.7) ve 923 erkek (\%61.3) olmak üzere toplam 1506 öğrenci araştırmanın örneklemini oluşturmuştur. Ölçekler yüz yüze görüşme tekniği ile uygulanmıştır. Tablo 1'de örneklem grubuna ait betimsel veriler yer almaktadır.

Tablo 1. Örnekleme Ait Betimsel İstatistiki Bilgiler

\begin{tabular}{|c|c|c|c|}
\hline Değişkenler & & $n$ & $\%$ \\
\hline \multirow{2}{*}{ Cinsiyet } & Kadin & 583 & 38.7 \\
\hline & Erkek & 923 & 61.3 \\
\hline \multirow{2}{*}{ Topluluk üyeliği } & Evet & 527 & 35 \\
\hline & Hayır & 979 & 65 \\
\hline \multirow{5}{*}{ Sinif } & 1.sinif & 421 & 28 \\
\hline & $2 . \sin 1 f$ & 477 & 31.7 \\
\hline & 3. sinif & 340 & 22.6 \\
\hline & 4. sinif & 199 & 13.2 \\
\hline & 5. sinıf ve üzeri & 69 & 4.6 \\
\hline \multirow{2}{*}{ Öğretim türü } & 1.öğretim & 1178 & 78.2 \\
\hline & 2.öğretim & 328 & 21.8 \\
\hline \multirow{2}{*}{ Spor yapma durumu } & Evet & 353 & 23.4 \\
\hline & Hayır & 1153 & 76.6 \\
\hline \multirow{8}{*}{ Birimler } & Mühendislik Fakültesi & 139 & 9.2 \\
\hline & İktisadi ve İdari Bilimler Fakültesi & 209 & 13.9 \\
\hline & Spor Bilimleri Fakültesi & 275 & 18.3 \\
\hline & Sağlık Bilimleri Fakültesi & 82 & 5.4 \\
\hline & Fen-Edebiyat Fakültesi & 74 & 4.9 \\
\hline & Honaz MYO & 133 & 8.8 \\
\hline & Fizik Tedavi ve Rehabilitasyon YO & 38 & 2.5 \\
\hline & Turizm Fakültesi & 41 & 2.7 \\
\hline -Fakülte & Tavas MYO & 29 & 1.9 \\
\hline -Meslek Yüksekokulu (MYO) & Eğitim Fakültesi & 77 & 5.1 \\
\hline \multirow[t]{7}{*}{-Yüksekokul (YO) } & İlahiyat Fakültesi & 25 & 1.7 \\
\hline & Diğer & 90 & 6 \\
\hline & Uygulamalı Bilimler YO & 165 & 11 \\
\hline & Kale MYO & 28 & 1.9 \\
\hline & Bekili MYO & 28 & 1.9 \\
\hline & Acıpayam MYO & 23 & 1.5 \\
\hline & Çivril Atasay Kamer MYO & 50 & 3.3 \\
\hline
\end{tabular}

Tablo 1'de görüldüğü üzere, çalışmaya, 583 kadın (\%37.7) ve 923 erkek (\%61.3) olmak üzere toplam 1506 öğrenci katılmıştır. Öğrencilerin \%61.2’si fakültelerde (n:922), \%19.3’ü meslek yüksek okullarında (n:291) ve \%19.5’i ise yüksek okullarda eğitim görmektedir. Çoğunluğu (\%78.2) 1. öğretimde okuyan bu ögrencilerin, \%28'i birinci sınıfta, \%31.7'si ikinci sınıfta, \%22.6's1 üçüncü sınıfta, \%13.2'si ise son sınıfta öğrenimlerini sürdürürken; \%4.6's1 ise azami öğrenim sürelerini aşarak eğitimlerine devam etmektedirler. Çalışmaya en fazla katılım gösteren birim Spor Bilimleri Fakültesi (\%18.3) olurken; en az katılım gösteren birim ise Acıpayam MYO (\%1.5) olmuştur. Katılımcıların spor yapma yüzdelerine bakıldığında ise, spor yapan öğrencilerin azınlıkta olduğu (\%23.4); spor yapmayan öğrencilerinse daha fazla yüzdeye (\%76.6) sahip olduğu görülmüştür. Öğrencilerin \%65'inin üniversite içerisindeki topluluklara dahil olmadığı, \%35’ininse topluluklarda görev aldığ1 tespit edilmiştir. 


\section{Veri Toplama Araçları}

Kişisel Bilgi Formu: Araştırmacılar tarafından hazırlanan kişisel bilgi formlarında öğrencilerin, cinsiyet, sınıf, ögretim türü, spor yapma durumu, üniversite tercih sebebi, topluluk üyeliği, fakülte ve ikametgah bilgilerine ilişkin ifadeler yer almaktadır.

Üniversite Yaşam Kalitesi Ölçeği: Üniversite yaşam kalitesi ölçeği, öğrencilerin üniversitedeki demokratik yaşam kültürü hakkındaki görüsslerinin belirlenmesine yönelik olarak Doğanay ve Sar1 (2006) tarafindan geliştirilmiştir. Ölçek, öğretim elemanı-öğrenci iletişimi ( $\alpha: .78)$, kimlik ( $\alpha: .89)$, sosyal olanaklar ( $\alpha: .53)$, kararlara kattlım ( $\alpha .73)$, öğrenci-öğrenci iletişimi ( $\alpha: 54)$, gelecek ( $\alpha: .90)$ ve sınıf ortamı ( $\alpha .65)$ olarak toplam 7 alt boyut ve 33 maddeden oluşmaktadır. Beşli likert olarak düzenlenen ölçekte ters puanlama bulunmamaktadır. Toplam varyansın \%58.81'ini açıklayan ölçeğin tamamına ait iç tutarlık kat sayısı ise .84 olarak tespit edilmiştir. Alt boyutlardan alınan ortalama puanlar yükseldikçe yaşam kalitesi de yükselmektedir.

Üniversite İmajı Ölçeği: Öğrencilerin algılarına göre üniversitenin imaj düzeyini saptamak için, Kazoleas, Kim ve Moffitt (2001) tarafindan geliştirilen ve Polat (2011) tarafindan uyarlanan üniversite imaj algis1 ölçeği 37 maddelik beşli likert tipi bir ölçektir. Kocaeli Üniversitesi örneği olarak geliştirilen ölçeğe ait maddelerden KOÜ ifadesi çıkarılmış ve yerine PAÜ ifadesi konmuştur. Ancak, maddelerin içeriğine sadık kalınarak bu değişikliğin dışında ifadelerde herhangi bir değişikliğe gidilmemiştir. Ölçek, kalite imajı ( $\alpha . .91)$, program imaj1 $(\alpha: .79)$, spor imaj1 $(\alpha: .85)$, genel görünüm ve fiziki altyapı imaj1 $(\alpha: .88)$, sosyal ortam imaj1 $(\alpha: .83)$, eğlence imaj1 $(\alpha: .84)$ ve barınma-beslenme imaj1 ( $\alpha .63)$ olmak üzere 7 alt boyutta toplanmıştır. Toplam varyansın \%67.50'sini açıklayan ölçeğin tamamına ait iç tutarlık kat sayısı ise .96 olarak tespit edilmiştir. İlgili alt boyutlara yönelik olarak öğrencilerin imaj alg1 düzeyleri 1.00-1.79 "oldukça düşük", 1.80-2.59 "düşük", 2.60-3.39 "orta”, 3.40-4.19 “yüksek", 4.20-5.00 aralı̆̆1 "oldukça yüksek" olarak değerlendirilmektedir.

Örgütsel Özdeşlessme Ölçeğg: Örgütsel özdeşleşmenin belirlenmesinde Mael ve Ashforth (1992) tarafindan geliştirilen Tak ve Aydemir (2004) tarafindan uyarlanan ölçek, toplam 6 ifade ve tek faktörden oluşmaktadır. Toplam varyansın \%59.32'sini açıklayan ölçeğin iç tutarlık kat sayısı ise .86 olarak tespit edilmiştir. Ölçekten alınan puan yükseldikçe özdeşleşme düzeyi artmaktadır.

\section{Verilerin Analizi}

Elde edilen veriler, farklılık ve ilişki analizleri ile çözümlenmiştir. Değişkenler arası farklılıkların tespiti için ilişkisiz örneklemler için t-testi; ilişkilerin tespiti içinse korelasyon ve regresyon analizleri SPSS 20 programında uygulanmıştır. Korelasyon değerleri kuvvet açısından Büyüköztürk (2016, s.32) referans alınarak (.00 ila .30 arası düşük, .30 ila .70 arası orta ve .70 ila 1.00 arası yüksek düzeyde ilişki) değerlendirilmiş ve regresyon analizi sonuçlannna göre de regresyon modelleri kurulmuştur (Can, 2014, s.292).

\section{Bulgular}

Bu bölümde araştırmanın amacına uygun olarak gerçekleştirilen analizlerin bulguları yer almaktadır. Tablo 2'de öğrencilerin ölçeklerden aldıkları puan ortalamalarının cinsiyete göre karılaştırılması yer almaktadir.

Cinsiyete göre incelenen ölçeklerde (tablo 2); örgütsel imaj ölçeği alt boyutlarından, kalite $\left[\mathrm{t}_{(1504)}=5.531 ; \mathrm{p}=.00<.05\right]$, program $\left[\mathrm{t}_{(1504)}=3.214 ; \mathrm{p}=.00<.05\right]$, spor $\left[\mathrm{t}_{(1173.57)}=2.524 ; \mathrm{p}=.01<.05\right]$, genel görünüm ve altyap1 $\left[\mathrm{t}_{(1504)}=2.667 ; \mathrm{p}=.00<.05\right]$, sosyal ortam $\left[\mathrm{t}_{(1504)}=4.550 ; \mathrm{p}=.00<.05\right]$, barnnma-beslenme $\left[\mathrm{t}_{(1504)}=5.853 ; \mathrm{p}=.00<.05\right]$ alt boyutlarında kadınlar lehine anlamlı farklılıklar görülmektedir. Eğlence imaj1 alt boyutunda cinsiyete göre herhangi bir anlamlı farklılık bulunamamıştır $\left[\mathrm{t}_{(1504)}=1.271 ; \mathrm{p}=.20>.05\right]$. Üniversite yaşam kalitesi cinsiyetler açısından ele alındığında, öğretim elemanı-öğrenci iletişimi $\left[\mathrm{t}_{(1504)}=5.987 ; \mathrm{p}=.00<.05\right]$, kararlara katıllım $\left[\mathrm{t}_{(1504)}=2.653 ; \mathrm{p}=.00<.05\right]$, ögrenci-öğrenci iletişimi $\left[\mathrm{t}_{(1504)}=3.631 ; \mathrm{p}=.00<.05\right]$, gelecek $\left[\mathrm{t}_{(1504)}=4.947 ; \mathrm{p}=.00<.05\right]$ ve sinif ortam $\left[\mathrm{t}_{(1504)}=3.116 ; \mathrm{p}=.00<.05\right]$ alt boyutlarında yine kadınlar lehine anlamlı farklılık tespit edilmiştir. Kimlik $\left[\mathrm{t}_{(1504)}=-.887 ; \mathrm{p}=.37>.05\right]$ ve sosyal olanak $\left[\mathrm{t}_{(1504)}=1.191 ; \mathrm{p}=.23>.05\right]$ alt boyutlarında ise cinsiyete göre herhangi bir anlamlı farkll11k

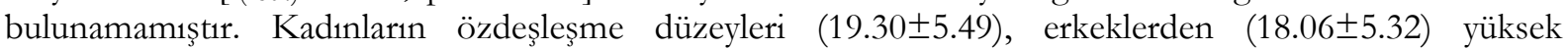
bulunarak, aralarında anlamlı bir farkllilk tespit edilmiştir $\left[\mathrm{t}_{(1504)}=4.371 ; \mathrm{p}=.00<.05\right]$. 
Tablo 2. Ölçekten Alınan Puan Ortalamalarnmn Cinsiyete Göre Karşılaștırılması

\begin{tabular}{|c|c|c|c|c|c|c|c|c|}
\hline & & Cinsiyet & $n$ & $\bar{X}$ & $S S$ & $t$ & $s d$ & $p$ \\
\hline \multirow{14}{*}{ 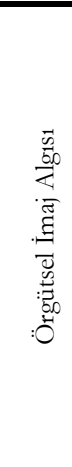 } & \multirow{2}{*}{ Kalite İmaj1 } & Kadin & 583 & 3.22 & .84 & 5.531 & 1504 & $.00^{*}$ \\
\hline & & Erkek & 923 & 2.97 & .86 & & & \\
\hline & \multirow{2}{*}{ Program İmaj1 } & Kadin & 583 & 2.99 & .72 & 3.214 & 1504 & $.00^{*}$ \\
\hline & & Erkek & 923 & 2.87 & .70 & & & \\
\hline & \multirow{2}{*}{ Spor İmaj1 } & Kadin & 583 & 3.00 & 1.12 & 2.524 & 1504 & $.01^{*}$ \\
\hline & & Erkek & 923 & 2.86 & 1.05 & & & \\
\hline & \multirow{2}{*}{ Genel Görünüm ve Altyapı İmaj1 } & Kadin & 583 & 3.08 & .98 & 2.667 & 1504 & $.00^{*}$ \\
\hline & & Erkek & 923 & 2.94 & .92 & & & \\
\hline & \multirow{2}{*}{ Sosyal Ortam İmaj1 } & Kadin & 583 & 3.05 & .93 & 4.550 & 1504 & $.00^{*}$ \\
\hline & & Erkek & 923 & 2.83 & .88 & & & \\
\hline & \multirow{2}{*}{ Eğlence İmaj1 } & Kadin & 583 & 2.79 & 1.21 & 1.271 & 1504 & .20 \\
\hline & & Erkek & 923 & 2.71 & 1.13 & & & \\
\hline & \multirow{2}{*}{ Barınma-Beslenme İmaj1 } & Kadin & 583 & 3.02 & .92 & 5.853 & 1504 & $.00^{*}$ \\
\hline & & Erkek & 923 & 2.74 & .88 & & & \\
\hline \multirow{14}{*}{ 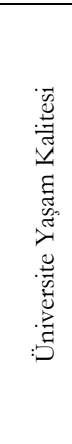 } & \multirow{2}{*}{ Öğretim Elemanı - Öğrenci İletişimi } & Kadin & 583 & 3.11 & .79 & 5.987 & 1504 & $.00^{*}$ \\
\hline & & Erkek & 923 & 2.87 & .76 & & & \\
\hline & \multirow{2}{*}{ Kimlik } & Kadin & 583 & 2.87 & 1.01 & -.887 & 1504 & .37 \\
\hline & & Erkek & 923 & 2.92 & 1.00 & & & \\
\hline & \multirow{2}{*}{ Sosyal Olanak } & Kadin & 583 & 3.11 & .73 & 1.191 & 1504 & .23 \\
\hline & & Erkek & 923 & 3.07 & .66 & & & \\
\hline & \multirow{2}{*}{ Kararlara Katılım } & Kadin & 583 & 3.13 & .75 & 2.653 & 1504 & $.00^{*}$ \\
\hline & & Erkek & 923 & 3.02 & .73 & & & \\
\hline & \multirow{2}{*}{ Öğrenci-Öğrenci İletişimi } & Kadin & 583 & 3.26 & .75 & 3.631 & 1504 & $.00^{*}$ \\
\hline & & Erkek & 923 & 3.11 & .75 & & & \\
\hline & \multirow{2}{*}{ Gelecek } & Kadin & 583 & 3.12 & 1.04 & 4.947 & 1504 & $.00^{*}$ \\
\hline & & Erkek & 923 & 2.85 & 1.04 & & & \\
\hline & \multirow{2}{*}{ Sinif Ortam } & Kadin & 583 & 3.25 & .83 & 3.116 & 1504 & $.00^{*}$ \\
\hline & & Erkek & 923 & 3.11 & .83 & & & \\
\hline \multirow{2}{*}{\multicolumn{2}{|c|}{ Özdeşleşme }} & Kadın & 583 & 3.21 & .91 & 4.371 & 1504 & $.00^{*}$ \\
\hline & & Erkek & 923 & 3.00 & .89 & & & \\
\hline
\end{tabular}

Tablo 3'te öğrencilerin topluluklara üye olma durumlarına göre karşılaştırılması amacıyla yapılan ttesti analiz sonuçlanna yer verilmiştir.

Tablo 3. Ögrencilerin Görïslerinin Topluluklara Üye Olma Durumlarna Göre Karşılasstırlması

\begin{tabular}{|c|c|c|c|c|c|c|c|c|}
\hline & & Topluluk üyeliği & $n$ & $\bar{X}$ & $S S$ & $t$ & $s d$ & $\bar{p}$ \\
\hline \multirow{14}{*}{ 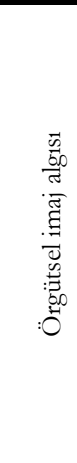 } & \multirow{2}{*}{ Kalite İmaj1 } & Evet & 527 & 28.07 & 7.72 & 1.727 & 1504 & .08 \\
\hline & & Hayır & 979 & 27.35 & 7.75 & & & \\
\hline & \multirow{2}{*}{ Program İmaj1 } & Evet & 527 & 23.60 & 5.84 & 1.484 & 1504 & .13 \\
\hline & & Hayır & 979 & 23.15 & 5.57 & & & \\
\hline & \multirow{2}{*}{ Spor İmaj1 } & Evet & 527 & 9.18 & 3.16 & 3.808 & 1504 & $.00^{*}$ \\
\hline & & Hayır & 979 & 8.52 & 3.29 & & & \\
\hline & \multirow{2}{*}{$\begin{array}{l}\text { Genel Görünüm ve Altyap1 } \\
\text { İmaj1 }\end{array}$} & Evet & 527 & 18.64 & 5.30 & 3.334 & 1170.33 & $.00^{*}$ \\
\hline & & Hayır & 979 & 17.62 & 5.84 & & & \\
\hline & \multirow{2}{*}{ Sosyal Ortam İmaj1 } & Evet & 527 & 11.80 & 3.73 & 1.040 & 1504 & .29 \\
\hline & & Hayır & 979 & 11.59 & 3.56 & & & \\
\hline & \multirow{2}{*}{ Eğlence İmaj1 } & Evet & 527 & 5.55 & 2.31 & .704 & 1504 & .48 \\
\hline & & Hayır & 979 & 5.46 & 2.34 & & & \\
\hline & \multirow{2}{*}{ Barınma-Beslenme İmaj1 } & Evet & 527 & 8.71 & 2.62 & 1.757 & 1504 & .07 \\
\hline & & Hayır & 979 & 8.45 & 2.75 & & & \\
\hline \multirow{14}{*}{ 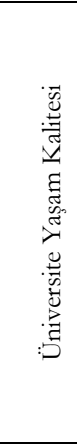 } & \multirow{2}{*}{$\begin{array}{l}\text { Öğretim Elemanı - Öğrenci } \\
\text { İletişimi }\end{array}$} & Evet & 527 & 17.90 & 4.62 & .518 & 1504 & .60 \\
\hline & & Hayır & 979 & 17.76 & 4.69 & & & \\
\hline & \multirow{2}{*}{ Kimlik } & Evet & 527 & 14.00 & 4.92 & -2.885 & 1504 & $.00^{*}$ \\
\hline & & Hayır & 979 & 14.79 & 5.09 & & & \\
\hline & \multirow{2}{*}{ Sosyal Olanak } & Evet & 527 & 15.60 & 3.40 & 1.310 & 1504 & .19 \\
\hline & & Hayır & 979 & 15.36 & 3.49 & & & \\
\hline & \multirow{2}{*}{ Kararlara Katılim } & Evet & 527 & 18.18 & 4.57 & -1.476 & 1504 & .14 \\
\hline & & Hayır & 979 & 18.54 & 4.41 & & & \\
\hline & \multirow{2}{*}{ Öğrenci-Öğrenci İletişimi } & Evet & 527 & 12.59 & 2.94 & -.963 & 1504 & .33 \\
\hline & & Hayır & 979 & 12.75 & 3.04 & & & \\
\hline & \multirow{2}{*}{ Gelecek } & Evet & 527 & 9.19 & 3.17 & 2.784 & 1504 & $.00^{*}$ \\
\hline & & Hayır & 979 & 8.72 & 3.12 & & & \\
\hline & \multirow{2}{*}{ Sinif Ortamı } & Evet & 527 & 12.44 & 3.31 & -2.083 & 1504 & $.03^{*}$ \\
\hline & & Hayır & 979 & 12.82 & 3.36 & & & \\
\hline \multirow{2}{*}{\multicolumn{2}{|c|}{ Özdeşleşme }} & Evet & 527 & 18.62 & 5.64 & .425 & 1021.77 & .67 \\
\hline & & Hayır & 979 & 18.50 & 5.30 & & & \\
\hline
\end{tabular}


Öğrencilerin topluluklara üye olma durumlarına göre incelenen ölçeklerde; örgütsel imaj ölçeği alt boyutlarından, spor imaj1 $\left[\mathrm{t}_{(1504)}=3.808 ; \mathrm{p}=.00<.05\right]$ ve genel görünüm ve altyap1 imajının $\left[\mathrm{t}_{(1504)}=3.433\right.$; $\mathrm{p}=.00<.05]$ topluluklara üye olan kişilerde daha fazla olduğu, üye olmayanlara göre aralarında anlamlı bir farklılık olduğu tespit edilmiştir. Diğer imaj alt boyutlarında herhangi bir farkllık bulunamamıştır ( $\mathrm{p}>.05)$.

Üniversite yaşam kalitesi ele alındığında, kimlik $\left[\mathrm{t}_{(1504)}=-2.885 ; \mathrm{p}=.00<.05\right]$, gelecek $\left[\mathrm{t}_{(1504)}=2.784\right.$; $\mathrm{p}=.00<.05]$ ve sınıf ortam $\left[\mathrm{t}_{(1504)}=-2.083 ; \mathrm{p}=.03<.05\right]$ alt boyutlarında anlamlı farkll1ıklar tespit edilmiştir. Kimlik ve sınıf ortamı alt boyutlannda üye olmayan kişilerin ortalamaları daha yüksek bulunurken; gelecek alt boyutunda ise üye olanların ortalaması daha yüksek çıkmıştır. Diğer yaşam kalitesi alt boyutları ve özdeşleşme düzeylerinin topluluğa üye olmak üzerinde anlamlı bir farklıllğı olmadığ1 görülmüştür ( $>$ >.05).

Tablo 4'te öğrencilerin spor yapma durumlarına göre karşılaştırlması amacıyla yapılan t-testi analizi sonuçlarına yer verilmiştir.

Tablo 4. Öğrencilerin Görüsslerinin Spor Yapma Durumlarna Göre Karşılaştırlması

\begin{tabular}{|c|c|c|c|c|c|c|c|c|}
\hline & & $\begin{array}{l}\text { Spor } \\
\text { Yapma }\end{array}$ & $n$ & $\bar{X}$ & $S \boldsymbol{S}$ & $t$ & sd & $p$ \\
\hline \multirow{14}{*}{ 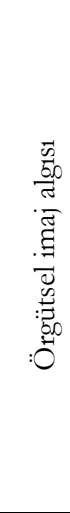 } & \multirow{2}{*}{ Kalite İmaj1 } & Evet & 353 & 3.27 & .81 & \multirow{2}{*}{5.250} & \multirow{2}{*}{1504} & \multirow{2}{*}{$.00^{*}$} \\
\hline & & Hayır & 1153 & 3.00 & .86 & & & \\
\hline & \multirow{2}{*}{ Program İmajı } & Evet & 353 & 3.09 & .67 & \multirow{2}{*}{5.423} & \multirow[b]{2}{*}{1504} & \multirow[b]{2}{*}{$.00^{*}$} \\
\hline & & Hayır & 1153 & 2.86 & .71 & & & \\
\hline & \multirow{2}{*}{ Spor İmaj1 } & Evet & 353 & 3.30 & .96 & \multirow{2}{*}{8.266} & \multirow{2}{*}{653.20} & \multirow{2}{*}{$.00^{*}$} \\
\hline & & Hayır & 1153 & 2.80 & 1.09 & & & \\
\hline & \multirow{2}{*}{ Genel Görünüm ve Altyap 1 İmaj1 } & Evet & 353 & 3.25 & .82 & \multirow{2}{*}{6.313} & \multirow{2}{*}{669.73} & \multirow{2}{*}{$.00^{*}$} \\
\hline & & Hayır & 1153 & 2.91 & .96 & & & \\
\hline & \multirow{2}{*}{ Sosyal Ortam İmaj1 } & Evet & 353 & 3.11 & .89 & \multirow{2}{*}{4.759} & \multirow{2}{*}{1504} & \multirow{2}{*}{$.00^{\circ}$} \\
\hline & & Hayır & 1153 & 2.85 & .90 & & & \\
\hline & \multirow{2}{*}{ Eğlence İmaj1 } & Evet & 353 & 2.95 & 1.14 & \multirow{2}{*}{3.847} & \multirow{2}{*}{1504} & \multirow{2}{*}{$.00^{\circ}$} \\
\hline & & Hayır & 1153 & 2.68 & 1.17 & & & \\
\hline & \multirow{2}{*}{ Barınma-Beslenme İmaj1 } & Evet & 353 & 2.98 & .828 & \multirow{2}{*}{3.316} & \multirow{2}{*}{642.42} & \multirow{2}{*}{$.00^{*}$} \\
\hline & & Hayır & 1153 & 2.80 & .92 & & & \\
\hline & & Evet & 353 & 3.07 & .75 & & & \\
\hline & Ugretim Elemanı - Ugrencı lletişımı & Hayır & 1153 & 2.93 & .78 & 2.989 & 1504 & $.00^{\prime}$ \\
\hline & Kimlik & Evet & 353 & 2.74 & .957 & -3416 & & \\
\hline. & & Hayır & 1153 & 2.95 & 1.02 & -3.410 & 1504 & $.00^{*}$ \\
\hline$\underline{\underline{\pi}}$ & Sosval Olanak & Evet & 353 & 3.18 & .69 & & & \\
\hline $\bar{\Xi}$ & Sosyal Olanak & Hayır & 1153 & 3.06 & .69 & 2.828 & 1504 & $.00^{*}$ \\
\hline జై & Kamarlare Katrlim & Evet & 353 & 3.10 & .77 & 020 & 1504 & \\
\hline$\approx$ & Kararlara Katilim & Hayır & 1153 & 3.05 & .74 & .929 & 1504 & .35 \\
\hline . & Ö̆̆renci-Ö̆̆̆renci İletisimi & Evet & 353 & 3.25 & .75 & 2101 & 1504 & $03^{*}$ \\
\hline$\stackrel{5}{5}$ & Ugrenc1-Ogrenc1 lletişimı & Hayır & 1153 & 3.15 & .75 & 2.101 & 1504 & .03 \\
\hline 点 & Gelecel & Evet & 353 & 3.20 & 1.04 & 4015 & 1504 & $\cap \Omega^{*}$ \\
\hline & Gelecek & Hayır & 1153 & 2.89 & 1.03 & 4.915 & 1504 & .00 \\
\hline & Sinif Ortam & Evet & 353 & 3.15 & .87 & -456 & 1504 & 64 \\
\hline & Sinit Urtami & Hayır & 1153 & 3.18 & .82 & -.450 & 1504 & .04 \\
\hline & & Evet & 353 & 3.16 & .87 & & & \\
\hline Uzde & me & Hayır & 1153 & 3.07 & .91 & 1.037 & 1504 & .10 \\
\hline
\end{tabular}

${ }^{*} \mathrm{p}<.05$

Tablo 4'te katılımcıların spor yapma durumlarına göre ölçeklerden aldıkları puanların karșılaștırma sonuçları verilmektedir. İmaj algııının tüm alt boyutlarında spor yapanlar lehine anlamlı farklılıklar tespit edilmiştir $(\mathrm{p}<.05)$. Spor yapan öğrencilerin imaj algilarının spor yapmayanlardan yüksek olduğu bulunmuştur $\left[\mathrm{t}_{(653.20)}=8.266 ; \mathrm{p}=.00<.05\right]$.

Yaşam kalitesi alt boyutlanından öğretim elemanı-öğrenci iletişimi [ $\left.\mathrm{t}_{(1504)}=2.989 ; \mathrm{p}=.00<.05\right]$, sosyal olanak [ $\left.\mathrm{t}_{(1504)}=2.828 ; \mathrm{p}=.00<.05\right]$, öğrenci-öğrenci iletişimi $\left[\mathrm{t}_{(1504)}=2.101 ; \mathrm{p}=.03<.05\right]$ ve gelecek $\left[\mathrm{t}_{(1504)}=4.915 ; \mathrm{p}=.00<.05\right]$ alt boyutlarında spor yapanların; kimlik alt boyutunda ise spor yapmayanların $\left[\mathrm{t}_{(1504)}=-3.416 ; \mathrm{p}=.00<.05\right]$ lehine anlamlı farklılık tespit edilmiştir. Spor yapmaya bağlı olarak özdeşleşme düzeyinde anlamlı bir farklılık olmadığ da gözlemlenmiştir $\left[\mathrm{t}_{(1504)}=1.637 ; \mathrm{p}=.10>.05\right]$.

Tablo 5’te ölçekler arasındaki ilisskilerin tespit edilmesi amacıyla yapılan Pearson Korelasyon analizi sonuçlarına yer verilmiştir. 
Tablo 5. Ölçekler Arası Korelasyon Değerleri

\begin{tabular}{|c|c|c|c|c|c|c|c|c|c|c|c|c|c|c|c|}
\hline & & İmaj1 & Imaj 2 & İmaj 3 & Imaj 4 & Imaj 5 & $\dot{I I m a j}_{6}$ & $\dot{I I m a j} 7$ & $Y K 8$ & YK9 & $Y K 10$ & YK 11 & $Y K 12$ & YK 13 & YK 14 \\
\hline \multirow{2}{*}{$Y K 8$} & $\mathrm{r}$ & .565 & .503 & .383 & .453 & .559 & .357 & .427 & 1 & & & & & & \\
\hline & $\mathrm{p}$ & $.000^{*}$ & $.000^{*}$ & $.000^{*}$ & $.000^{*}$ & $.000^{*}$ & $.000^{*}$ & $.000^{*}$ & & & & & & & \\
\hline \multirow{2}{*}{ YK9 } & $\mathrm{r}$ & -.366 & -.208 & -.210 & -.276 & -.245 & -.145 & -.168 & -.167 & 1 & & & & & \\
\hline & $\mathrm{p}$ & $.000 *$ & $.000 *$ & $.000 *$ & $.000 *$ & $.000^{*}$ & $.000^{*}$ & $.000^{*}$ & $.000 *$ & & & & & & \\
\hline \multirow{2}{*}{ YK10 } & $\mathrm{r}$ & .292 & .325 & .265 & .273 & .286 & .219 & .231 & .330 & .186 & 1 & & & & \\
\hline & $\mathrm{p}$ & $.000^{*}$ & $.000 *$ & $.000^{*}$ & $.000^{*}$ & $.000^{*}$ & $.000^{*}$ & $.000^{*}$ & $.000 *$ & $.000 *$ & & & & & \\
\hline \multirow{2}{*}{$Y K 11$} & $\mathrm{r}$ & .317 & .369 & .291 & .318 & .309 & .295 & .252 & .334 & .106 & .484 & 1 & & & \\
\hline & $\mathrm{p}$ & $.000 *$ & $.000 *$ & $.000 *$ & $.000 *$ & $.000^{*}$ & $.000 *$ & $.000^{*}$ & $.000 *$ & $.000 *$ & $.000 *$ & & & & \\
\hline \multirow{2}{*}{ YK12 } & $\mathrm{r}$ & .369 & .370 & .312 & .323 & .352 & .288 & .254 & .424 & -.022 & .395 & .448 & 1 & & \\
\hline & $\mathrm{p}$ & $.000^{*}$ & $.000 *$ & $.000^{*}$ & $.000^{*}$ & $.000^{*}$ & $.000^{*}$ & $.000^{*}$ & $.000^{*}$ & .401 & $.000^{*}$ & $.000 *$ & & & \\
\hline \multirow{2}{*}{ YK13 } & $\mathrm{r}$ & .631 & .553 & .467 & .523 & .530 & .456 & .475 & .515 & -.320 & .307 & .346 & .391 & 1 & \\
\hline & $\mathrm{p}$ & $.000 *$ & $.000 *$ & $.000 *$ & $.000 *$ & $.000^{*}$ & $.000 *$ & $.000 *$ & $.000 *$ & $.000 *$ & $.000 *$ & $.000^{*}$ & $.000^{*}$ & & \\
\hline \multirow{2}{*}{ YK14 } & $\mathrm{r}$ & .106 & .140 & .110 & .118 & .136 & .026 & .157 & .164 & .209 & .284 & .302 & .316 & .133 & 1 \\
\hline & p & $.000^{*}$ & $.000^{*}$ & $.000^{*}$ & $.000 *$ & $.000 *$ & .310 & $.000^{*}$ & $.000 *$ & $.000^{*}$ & $.000^{*}$ & $.000^{*}$ & $.000^{*}$ & $.000 *$ & \\
\hline \multirow{2}{*}{$\ddot{O Z Z 15}$} & $\mathrm{r}$ & .520 & .447 & .306 & .400 & .456 & .280 & .334 & .385 & -.232 & .204 & .231 & .278 & .375 & .140 \\
\hline & $\mathrm{p}$ & $.000 *$ & $.000 *$ & $.000^{*}$ & $.000^{*}$ & $.000^{*}$ & $.000^{*}$ & $.000^{*}$ & $.000 *$ & $.000 *$ & $.000^{*}$ & $.000^{*}$ & $.000^{*}$ & $.000^{*}$ & $.000 *$ \\
\hline
\end{tabular}

${ }^{*} \mathrm{p}<.05$

İmaj 1:Kalite İmaj1; İmaj 2:Program İmaj1; İmaj 3:Spor İmaj; İmaj 4:Genel Görünüm ve Altyap1 İmaji; İmaj 5:Sosval Ortam İmaji; İmaj 6:Ĕglence İmaj1; İmaj 7:Barınma-Beslenme İmaj1; YK8: Ögretim Elemanı-Öğrenci İletişimi; YK9: Kimlik; YK 10: Sosyal Olanak; YK 11: Kararlara Katıllım; YK 12: Öğrenci-Öğrenci İletișimi; YK 13: Gelecek; YK 14: Sinıf Ortamı; ÖZ15:Özdeșleșme

Ölçekler arası korelasyon değerlerine bakıldığında (tablo 5), ölçeklerin tüm alt boyutlarında orta ve düşük düzeyde pozitif anlamlı bir ilişki tespit edilmiştir $(\mathrm{p}<.05)$. Ancak yalnızca, yaşam kalitesi ölçeğinden kimlik alt boyutunun, imaj algisı ölçeğinin tüm alt boyutlarıyla ve özdeşleşme ölçeğiyle aralarında düşük düzeyde negatif anlamlı bir ilişki tespit edilmiştir $(\mathrm{p}<.05)$.

Tablo 6'da öğrencilerin algıladıkları üniversite imaj algısının özdeşleme düzeyine etkisini ölçmek amacıyla yapılan regresyon analizi sonuçlarına yer verilmiştir.

Tablo 6. Üniversite Imajinn Özdeşleme Düreyine Etkisine İliskin Regresyon Analizi Sonuclar

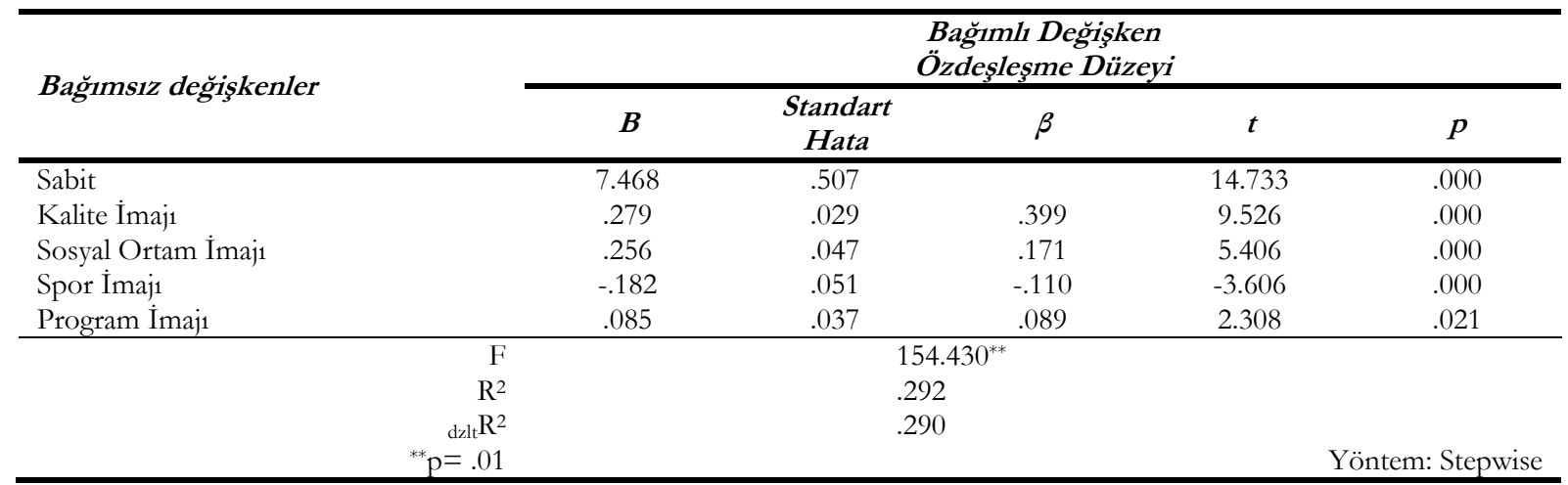

Üniversite imaj1 alt boyutlarından kalite, sosyal ortam, spor ve program imaj1, özdeşleşme düzeyini $\cong \% 29$ oranında açıklamaktadır $(\mathrm{F}=154.430, \mathrm{p}<.01)$. Aşamalı regresyon analizi sonuçlarına göre; genel görünüm ve altyapı, eğlenme ve barınma-beslenme imajı alt boyutlarının özdeşleşme düzeyi üzerindeki etkisi pozitif olmasına karşın, ilgili değişkenlere ait katsayıların anlamsız olduğu görülmektedir. Üniversite imaj ölçeğinden, özdeşleme düzeyi üzerinde en güçlü etkisi olan imaj, kalite imaji $(\beta=.399, \mathrm{p}<.01)$ olmuştur. Regresyon analizi sonuçlarnna göre, özdeşleşmeyi yordayan regresyon modeli şu şekildedir:

Özdeşleşme düzeyi $=(.279 \times$ Kalite İmajı Ölçek Puanı $)+(.256$ x Sosyal Ortam İmajı Ölçek Puanı $)+$ $(-.182$ x Spor İmajı Ölçek Puanı) + (.085 x Program İmajı Ölçek Puanı) + (7.468)

Tablo 7'de öğrencilerin üniversite yaşam kalitesinin özdeşleme düzeyine etkisini ölçmek amaciyla yapılan regresyon analizi sonuçlarına yer verilmiştir. 
Tablo 7. Üniversite Yaşam Kalitesinin Öz̨desleme Düzeyine Etkisine İliskkin Regresyon Analiẓi Sonuçlar

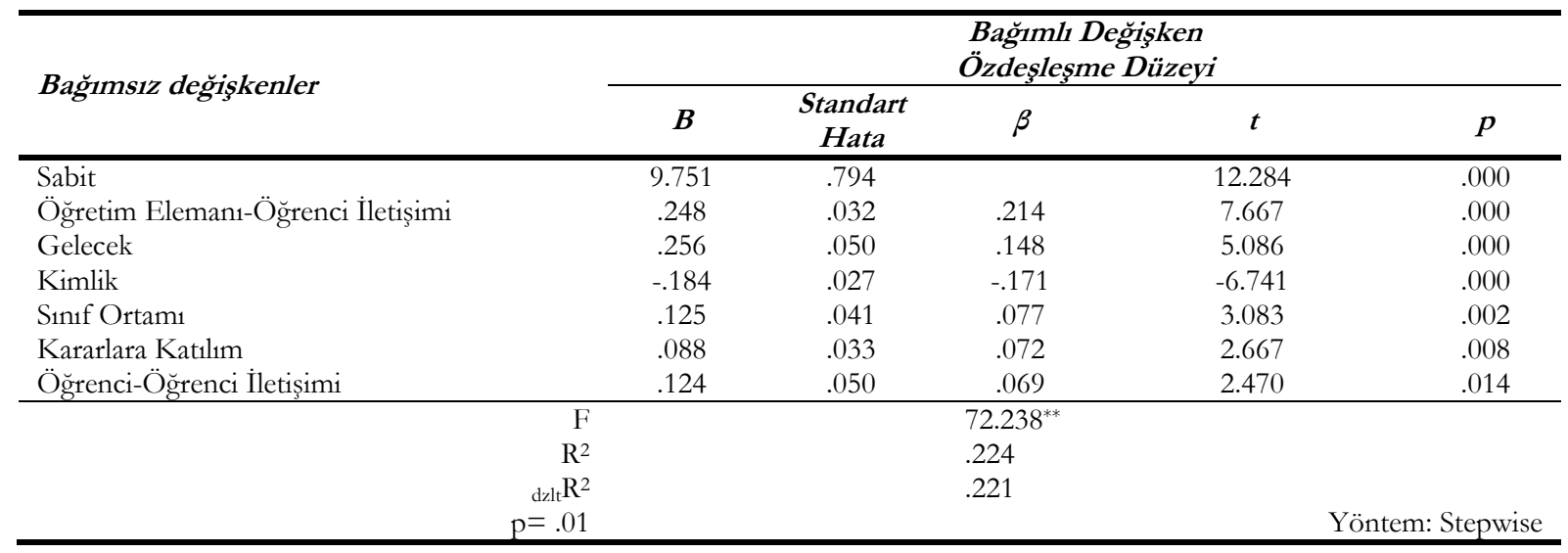

Üniversite yaşam kalitesi alt boyutlarından öğretim elemanı-öğrenci iletişimi, gelecek, kimlik, sınıf ortamı, kararlara katılım, öğrenci-öğrenci iletişimi özdeșleşme düzeyini $\cong \% 22$ oranında açıklamaktadır $(\mathrm{F}=72.238, \mathrm{p}<.01)$. Așamalı regresyon analizi sonuçlarına göre; sosyal olanak alt boyutunun özdeșleșme düzeyi üzerindeki etkisi pozitif olmasına karşın, ilgili değişkene ait katsayının anlamsız olduğu görülmüştür. Üniversite yaşam kalitesinin özdeşleme düzeyi üzerinde en güçlü etkisi, öğretim eleman1-öğrenci iletişimi $(\beta=.214, \mathrm{p}<.01)$ alt boyutunda görülmektedir. Regresyon analizi sonuçlarına göre, özdeşleşmeyi yordayan regresyon modeli şu şekildedir:

Özdeşleşme düzeyi $=(.248 \times$ Öğretim Elemanı-Öğrenci İletişimi Ölçek Puanı $)+(.256$ x Gelecek Ölçek Puanı $)+(-.184$ x Kimlik Ölçek Puanı $)+(.125$ x Sınıf Ortamı Ölçek Puanı) + (.088 x Kararlara Katılım Ölçek Puanı) + (.124 x Öğrenci-Öğrenci İletişimi Ölçek Puanı) + (9.751)

Tablo 8'de öğrencilerin üniversite yaşam kalitesinin, algıladıklanı üniversite kalite imajına etkisini ölçmek amacıyla yapılan regresyon analizi sonuçlarına yer verilmiştir.

Tablo 8. Kalite Imajina İlişkin Regresyon Analizi Sonuclar

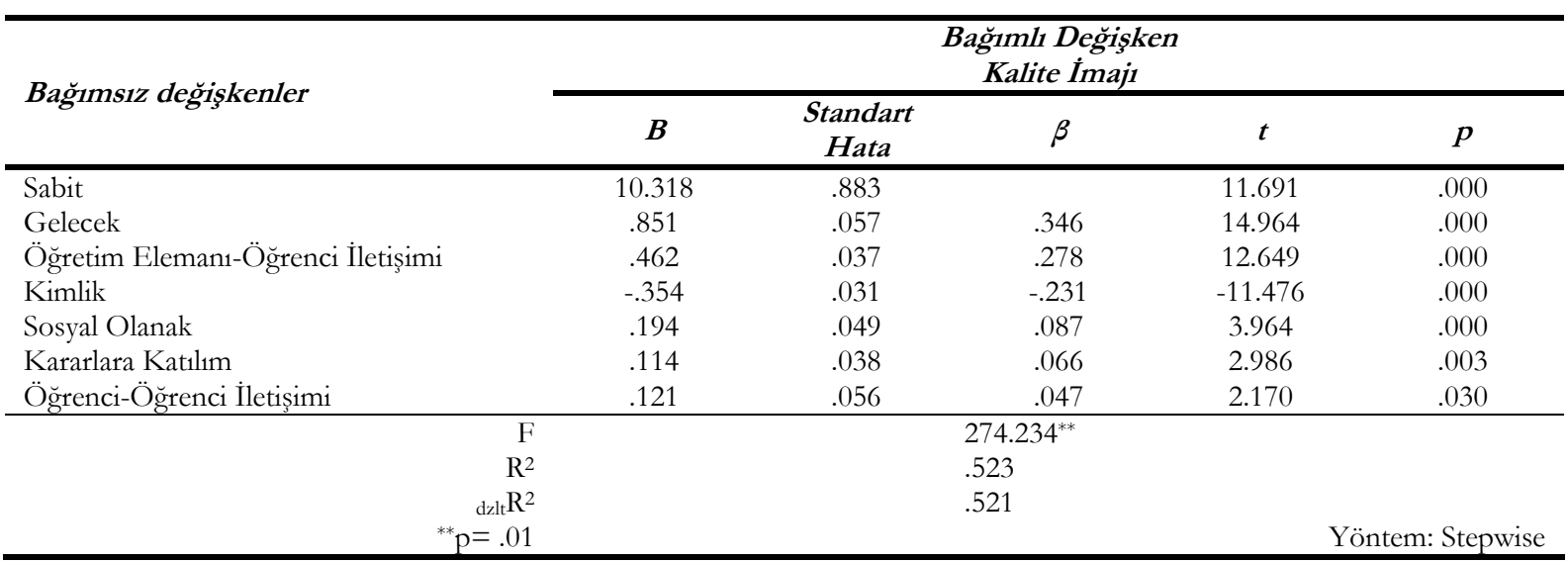

Kalite imaj algısına ilişkin kurulan regresyon analiz modelinde; üniversite yaşam kalitesi alt boyutlarından gelecek, öğretim elemanı-öğrenci iletişimi, kimlik, sosyal olanak, kararlara katılım, öğrenciöğrenci iletişimi alt boyutları öğrencilerin kalite imaj algısını $\cong 052$ oranında açıklamaktadır ( $\mathrm{F}=274.234$, $\mathrm{p}<.01)$. Aşamalı regresyon analizi sonuçlarına göre; sınıf ortamı alt boyutunun kalite imaj algısı üzerindeki etkisi pozitif olmasına karşın, ilgili değişkene ait katsayının anlamsız olduğu görülmektedir. Üniversite yaşam kalitesinin kalite imaj algisı üzerinde en güçlü etkisi, öğretim elemanı-öğrenci iletişimi $(\beta=.346$, $\mathrm{p}<.01)$ alt boyutunda görülmektedir. Regresyon analizi sonuçlarına göre, kalite imajını yordayan regresyon modeli şu şekildedir:

Kalite imaj1 $=(.851 \times$ Gelecek Ölçek Puanı $)+(.462 \times$ Öğretim Elemanı-Öğrenci İletişimi Ölçek Puanı $)+(-.354$ x Kimlik Ölçek Puanı $)+(.194$ x Sosyal Olanak Ölçek Puanı) + (.114 x Kararlara Katılım Ölçek Puanı) + (.121 x Öğrenci-Öğrenci İletişimi Ölçek Puanı) + (10.318)

Tablo 9'da öğrencilerin üniversite yaşam kalitesinin, algıladıkları üniversite program imajına etkisini ölçmek amacıyla yapılan regresyon analizi sonuçlarına yer verilmiştir. 
Tablo 9. Program İmajna İlişkin Regresyon Analizi Sonuçlar

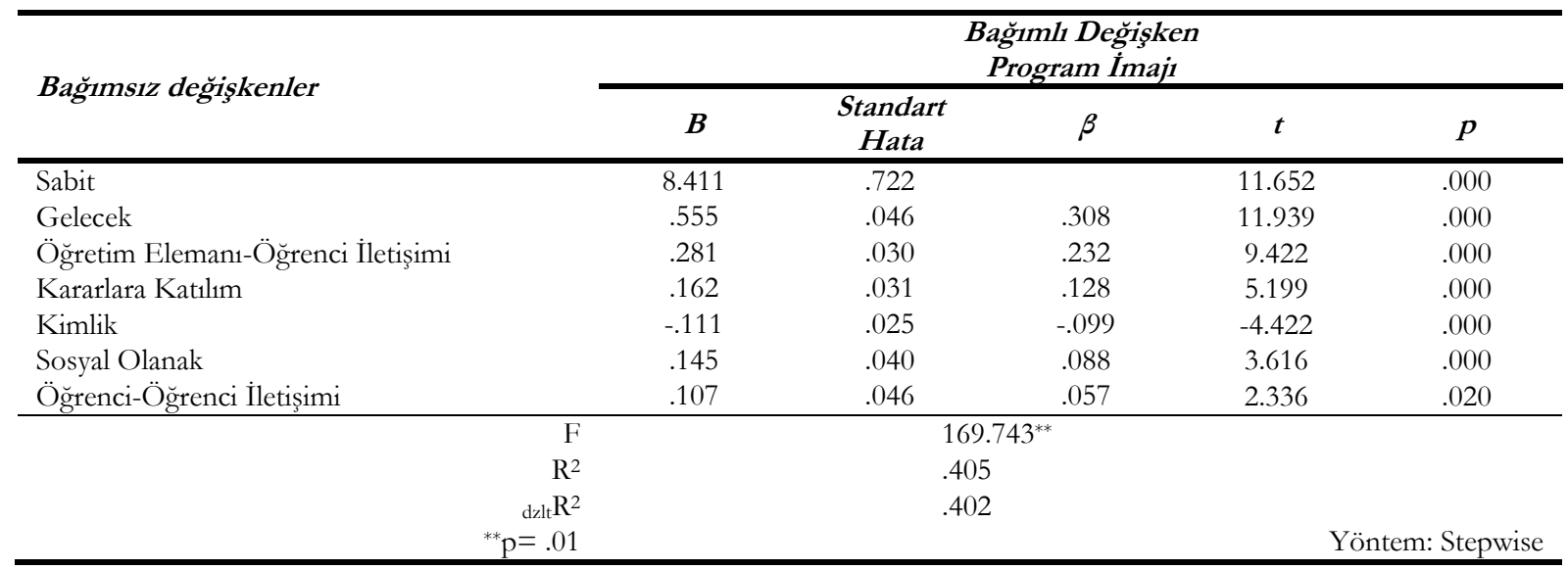

Program imaj algısına ilişkin kurulan regresyon analiz modelinde; üniversite yaşam kalitesi alt boyutlarından gelecek, öğretim elemanı-öğrenci iletişimi, kararlara katılım, kimlik, sosyal olanak, öğrenciöğrenci iletişimi alt boyutları öğrencilerin program imaj algısını $\cong \% 40$ oranında açıklamaktadır $(\mathrm{F}=169.743$, $\mathrm{p}<.01)$. Aşamalı regresyon analizi sonuçlarına göre; sınıf ortamı alt boyutunun program imaj algısı üzerindeki etkisi pozitif olmasına karşın, ilgili değişkene ait katsayının anlamsız olduğu görülmektedir. Üniversite yaşam kalitesinin program imaj algisı üzerinde en güçlü etkisi, gelecek $(\beta=.308, \mathrm{p}<.01)$ alt boyutunda görülmektedir. Regresyon analizi sonuçlarına göre, program imajını yordayan regresyon modeli şu şekildedir:

Program imaj1 $=(.555$ x Gelecek Ölçek Puanı $)+(.281$ x Öğretim Elemanı-Öğrenci İletişimi Ölçek Puanı) + (.162 x Kararlara Katılım Ölçek Puanı $)+(-.111 \times$ Kimlik Ölçek Puanı $)+(.145$ x Sosyal Olanak Ölçek Puanı) + (.107 x Öğrenci-Öğrenci İletişimi Ölçek Puanı) + (8.411)

Tablo 10'da öğrencilerin üniversite yaşam kalitesinin, algıladıkları üniversite spor imajına etkisini ölçmek amacıyla yapılan regresyon analizi sonuçlarına yer verilmiştir.

Tablo 10. Spor Imajina İlişkin Regresyon Analizi Sonuclar

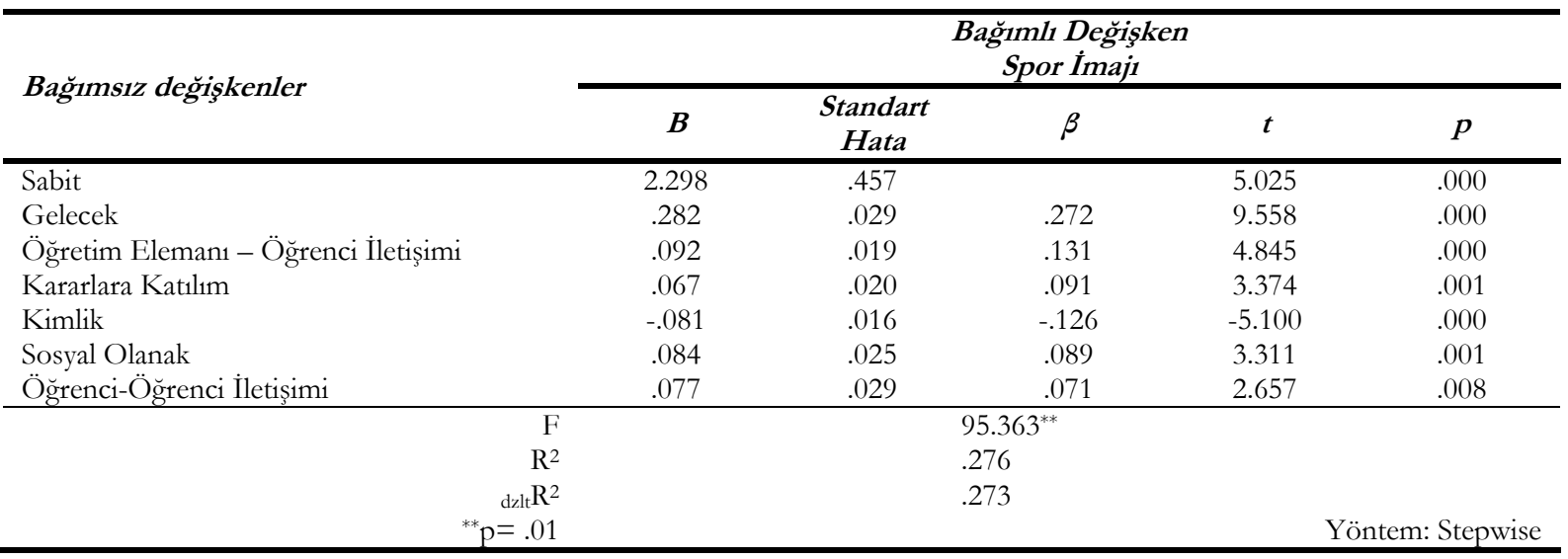

Spor imaj algısına ilişkin kurulan regresyon analiz modelinde; üniversite yaşam kalitesi alt boyutlarından gelecek, öğretim elemanı-öğrenci iletişimi, kararlara katılım, kimlik, sosyal olanak, öğrenciöğrenci iletişimi alt boyutları öğrencilerin spor imaj algısını $\cong \% 28$ oranında açılamaktadır $(\mathrm{F}=95.363$, $\mathrm{p}<.01)$. Aşamalı regresyon analizi sonuçlarına göre; sınıf ortamı alt boyutunun spor imaj algısı üzerindeki etkisi pozitif olmasına karşın, ilgili değişkene ait katsayının anlamsız olduğu görülmektedir. Üniversite yaşam kalitesinin spor imaj alg1s1 üzerinde en güçlü etkisi, gelecek $(\beta=.272, \mathrm{p}<.01)$ alt boyutunda görülmektedir. Regresyon analizi sonuçlarına göre, spor imajını yordayan regresyon modeli şu şekildedir:

Spor imaj1 $=(.282 \times$ Gelecek Ölçek Puanı $)+(.092 \times$ Öğretim Elemanı-Öğrenci İletişimi Ölçek Puanı $)+(.067$ x Kararlara Katılım Ölçek Puanı $)+(-.081 \times$ Kimlik Ölçek Puanı $)+(.084$ x Sosyal Olanak Ölçek Puanı $)+(.077$ x Öğrenci-Öğrenci İletişimi Ölçek Puanı $)+(2.298)$ 
Tablo 11'de öğrencilerin üniversite yaşam kalitesinin, algıladıkları üniversite genel görünüm ve alt yap1 imajına etkisini ölçmek amacıyla yapılan regresyon analizi sonuçlarına yer verilmiştir.

Tablo 11. Genel Görünüm ve Alt Yapr İmajina İliskin Regresyon Analizi Sonuclar

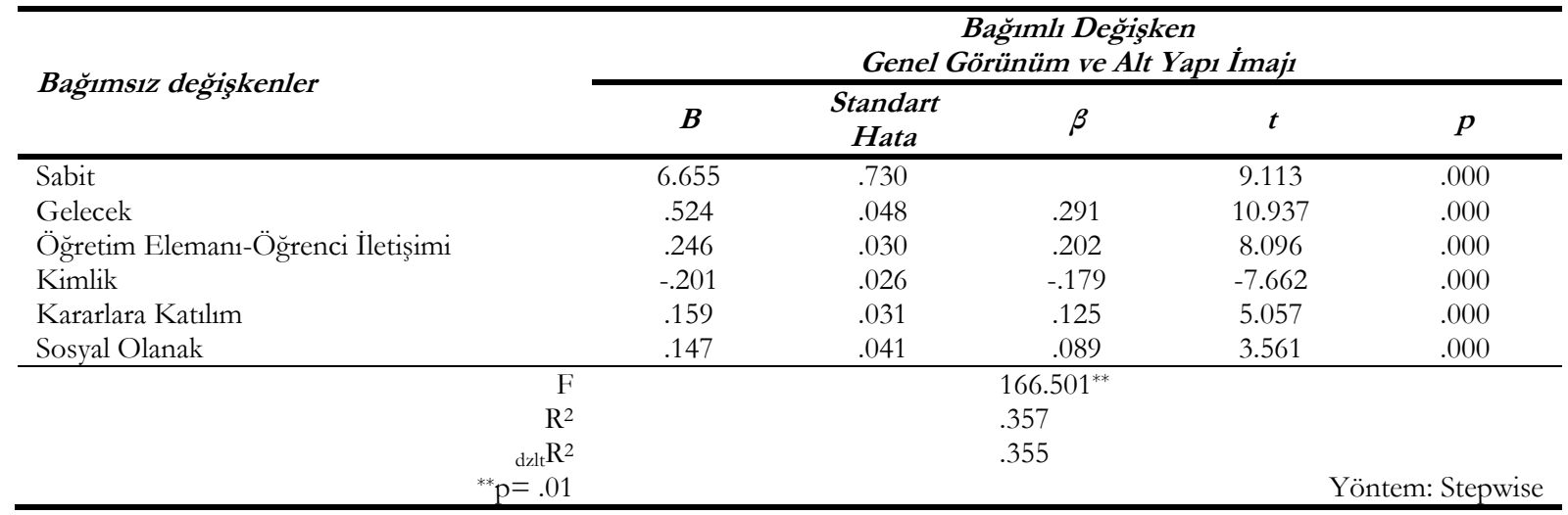

Genel görünüm ve alt yapı imaj algısına ilişkin kurulan regresyon analiz modelinde; üniversite yaşam kalitesi alt boyutlanından gelecek, ögrretim elemanı-öğrenci iletişimi, kimlik, kararlara katılım, sosyal olanak alt boyutları öğrencilerin genel görünüm ve alt yapı imaj algısını $\cong \% 36$ oranında açılamaktadır $(\mathrm{F}=166.501, \mathrm{p}<.01)$. Aşamalı regresyon analizi sonuçlarına göre; sınıf ortamı ve öğrenci-öğrenci iletişimi alt boyutlarının genel görünüm ve alt yapı imaj algısı üzerindeki etkisi pozitif olmasına karșın, ilgili değişkenlere ait katsayıların anlamsız olduğu görülmektedir. Üniversite yaşam kalitesinin genel görünüm ve alt yap1 imaj alg1s1 üzerinde en güçlü etkisi, gelecek $(\beta=.291, \mathrm{p}<.01)$ alt boyutunda görülmektedir. Regresyon analizi sonuçlarına göre, genel görünüm ve alt yapı imajını yordayan regresyon modeli şu şekildedir:

Genel görünüm ve alt yapı imajı $=(.524 \times$ Gelecek Ölçek Puanı $)+(.246$ x Öğretim Eleman1-Öğrenci İletişimi Ölçek Puanı) $+(-.201$ x Kimlik Ölçek Puanı $)+(.159$ x Kararlara Katılım Ölçek Puanı $)+(.147$ x Sosyal Olanak Ölçek Puanı) + (6.655)

Tablo 12'de öğrencilerin üniversite yaşam kalitesinin, algıladıkları üniversite sosyal ortam imajına etkisini ölçmek amacıyla yapılan regresyon analizi sonuçlarına yer verilmiştir.

Tablo 12. Sosyal Ortam Imajina İlişkin Regresyon Analizi Sonuclar

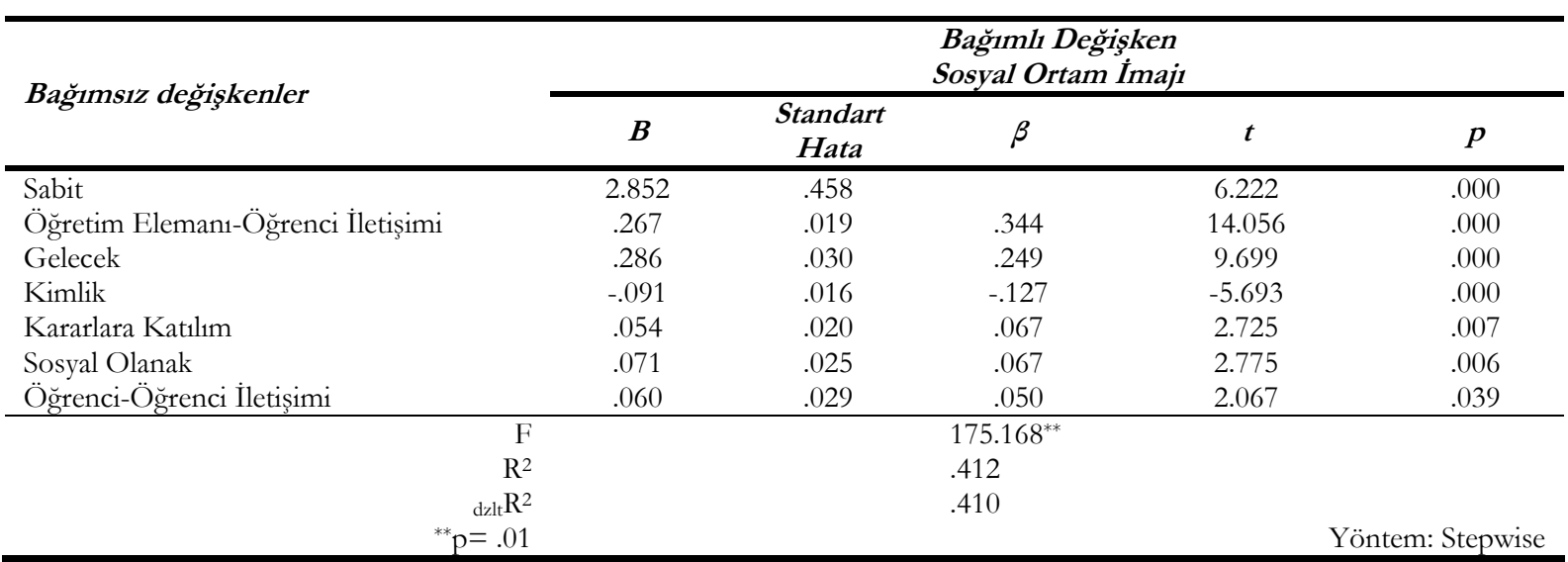

Sosyal ortam imaj algısına iliş̧in kurulan regresyon analiz modelinde; üniversite yaşam kalitesi alt boyutlarından öğretim elemanı-öğrenci iletişimi, gelecek, kimlik, kararlara katılım, sosyal olanak, öğrenciöğrenci iletişimi alt boyutları öğrencilerin sosyal ortam imaj algısını $\cong \% 41$ oranında açılamaktadır $(\mathrm{F}=175.168, \mathrm{p}<.01)$. Aşamalı regresyon analizi sonuçlarına göre; sınıf ortamı alt boyutunun sınıf ortamı imaj algısı üzerindeki etkisi pozitif olmasına karşın, ilgili değişkene ait katsayının anlamsız olduğu görülmektedir. Üniversite yaşam kalitesinin sosyal ortam imaj1 alg1sı üzerinde en güçlü etkisi, öğretim elemanı-öğrenci iletişimi $(\beta=.344, \mathrm{p}<.01)$ alt boyutunda görülmektedir. Regresyon analizi sonuçlarına göre, sosyal ortam imajını yordayan regresyon modeli şu şekildedir: 
Sosyal ortam imaj1 $=(.267 \times$ Öğretim Elemanı-Öğrenci İletişimi Ölçek Puanı) $+(.286$ x Gelecek Ölçek Puanı $)+(-.091 \times$ Kimlik Ölçek Puanı $)+(.054$ x Kararlara Katılım Ölçek Puanı $)+(.071$ x Sosyal Olanak Ölçek Puanı $)+(.060$ x Öğrenci-Öğrenci İletişimi Ölçek Puanı $)+(2.852)$

Tablo 13'te öğrencilerin üniversite yaşam kalitesinin, algıladıkları üniversite eğlence imajına etkisini ölçmek amacıyla yapılan regresyon analizi sonuçlarına yer verilmiştir.

Tablo 13. Eğlence Imajina İliskkin Regresyon Analizi Sonuçlar

\begin{tabular}{|c|c|c|c|c|c|c|}
\hline \multirow{2}{*}{ Bağımsız değişkenler } & & \multicolumn{5}{|c|}{$\begin{array}{c}\text { Bağımlı Değişken } \\
\text { Eğlence İmajı }\end{array}$} \\
\hline & & $B$ & $\begin{array}{c}\text { Standart } \\
\text { Hata }\end{array}$ & $\beta$ & $t$ & $p$ \\
\hline Sabit & & 1.054 & .299 & & 3.528 & .000 \\
\hline Gelecek & & .242 & .020 & .327 & 12.121 & .000 \\
\hline Kararlara Katılım & & .071 & .014 & .137 & 5.233 & .000 \\
\hline Öğretim Elemanı-Öğrenci İletişimi & & .063 & .014 & .126 & 4.638 & .000 \\
\hline Sinif Ortamı & & -.073 & .017 & -.104 & -4.345 & .000 \\
\hline Öğrenci-Öğrenci İletişimi & & .060 & .021 & .078 & 2.854 & .004 \\
\hline & $\mathrm{F}$ & & & $312^{* *}$ & & \\
\hline & $\mathrm{R}^{2}$ & & & & & \\
\hline & ${ }_{\mathrm{dzl} t \mathrm{R}} \mathrm{R}^{2}$ & & & & & \\
\hline & ${ }^{* *} \mathrm{p}=.01$ & & & & & Stepwise \\
\hline
\end{tabular}

Eğlence imaj aloısına ilişskin kurulan regresyon analiz modelinde; üniversite yașam kalitesi alt boyutlarından gelecek, kararlara katılım, öğretim elemanı-öğrenci iletişimi, sınıf ortamı, öğrenci-öğrenci iletişimi alt boyutları öğrencilerin eğlence imaj algısını $\cong \% 25$ oranında açıklamaktadır $(F=102.312, p<.01)$. Aşamalı regresyon analizi sonuçlarına göre; sosyal olanak ve kimlik alt boyutlarının eğlence imaj algısı üzerindeki etkisi pozitif olmasına karşın, ilgili değişkenlere ait katsayıların anlamsız olduğu görülmektedir. Üniversite yaşam kalitesinin eğlence imaj1 alg1s1 üzerinde en güçlü etkisi, gelecek $(\beta=.327, \mathrm{p}<.01)$ alt boyutunda görülmektedir. Regresyon analizi sonuçlarına göre, eğlence imajını yordayan regresyon modeli şu şekildedir:

Eğlence imajı $=(.242 \times$ Gelecek Ölçek Puanı $)+(.071 \times$ Kararlara Katılım Ölçek Puanı $)+(.063 \mathrm{x}$ Öğretim Elemanı-Öğrenci İletişimi Ölçek Puanı) + (-.073 x Sınıf Ortamı Ölçek Puanı) + (.060 x ÖğrenciÖğrenci İletişimi Ölçek Puanı) + (1.054)

Tablo 14’te öğrencilerin üniversite yaşam kalitesinin, algıladıkları üniversite barınma-beslenme imajına etkisini ölçmek amacıyla yapılan regresyon analizi sonuçlarına yer verilmiştir.

Tablo 14. Barnma-Beslenme Imajina İliskkin Regresyon Analizi Sonuclar

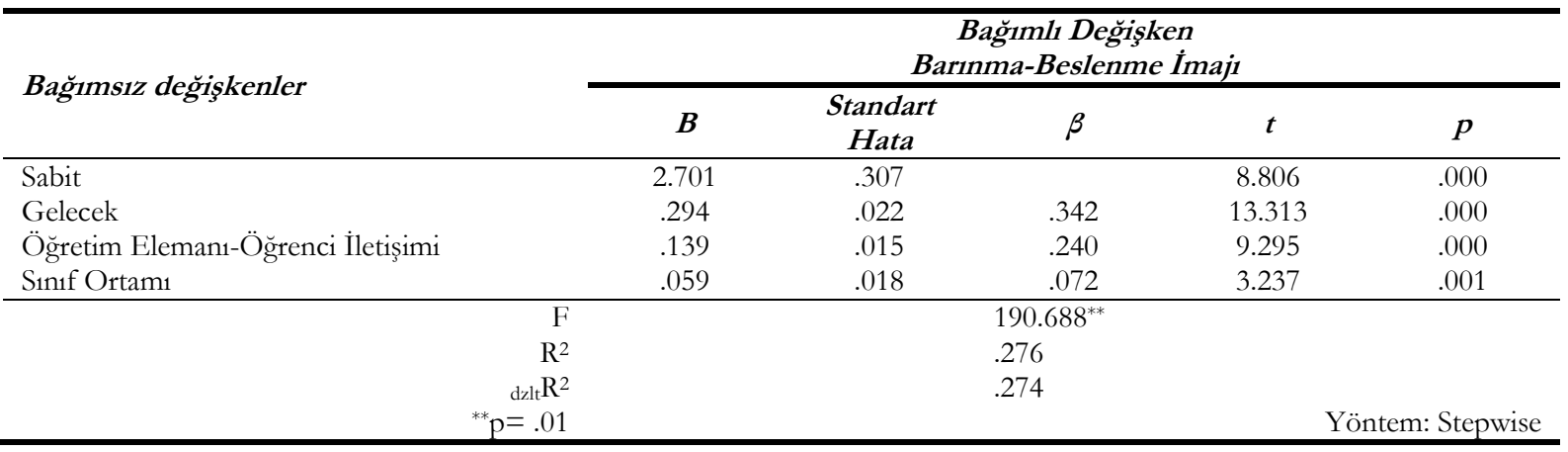

Barınma-beslenme imaj algısına ilişkin kurulan regresyon analiz modelinde; üniversite yaşam kalitesi alt boyutlarından gelecek, öğretim elemanı-öğrenci iletişimi, sınıf ortamı alt boyutları öğrencilerin barınmabeslenme imaj algısını $\cong \% 28$ oranında açıklamaktadır $(\mathrm{F}=190.688, \mathrm{p}<.01)$. Aşamalı regresyon analizi sonuçlarına göre; sosyal olanak, öğrenci-öğrenci iletişimi, kararlara kattlım ve kimlik alt boyutlarının barınma-beslenme imaj algısı üzerindeki etkisi pozitif olmasına karşın, ilgili değişkenlere ait katsayıların anlamsız olduğu görülmektedir. Üniversite yaşam kalitesinin barınma-beslenme imaj algısı üzerinde en güçlü etkisi, gelecek $(\beta=.342, \mathrm{p}<.01)$ alt boyutunda görülmektedir. Regresyon analizi sonuçlarına göre, barınma-beslenme imajını yordayan regresyon modeli şu şekildedir:

Barınma-Beslenme imaj1 $=(.294 \times$ Gelecek Ölçek Puanı $)+(.139 \times$ Öğretim Elemanı-Öğrenci İletişimi Ölçek Puanı) $+(.059$ x Sınıf Ortamı Ölçek Puanı $)+(2.701)$ 


\section{Tartışma, Sonuç ve Öneriler}

Pamukkale Üniversitesi öğrencilerinin yaşam kalitesi, örgütsel imaj ve özdeşleşme düzeyleri arasındaki ilişkilerin incelenmesi amacıyla yapılan bu çalısmanın bulgularına göre cinsiyet açısından değerlendirildiğinde örgütsel imaj ölçeğinin kalite, program, spor, genel görünüm ve altyapı, sosyal ortam, barınma-beslenme alt boyutlarında kadınların imaj algilarının erkeklere oranla daha yüksek olduğu görülmektedir. Karacabey vd., (2016, s.459) çalışmasında ise örgütsel imaja ilişkin algıların cinsiyete dayalı olarak farklılaşmadığı görülmüsştür. Yine Cerit (2006, s.343) ise eğitim fakültesi öğrencileri ile yaptığı çalışmada öğrencilerin üniversite ile ilgili imaj algılarında, cinsiyetin bir fark oluşturmadığını tespit etmiştir. Dolayısıyla bu çalışmalarda bu araştırmanın aksine cinsiyetin örgütsel imajı etkilemediği ifade edilebilir.

Cinsiyetler açısından üniversite yaşam kalitesi ele alındığında ise öğretim elemanı-öğrenci iletişimi, kararlara katılım, ögrenci-öğrenci iletişimi, gelecek ve sınıf ortamı alt boyutlarında yine kadınların yaşam kalitesi düzeylerinin erkeklere oranla daha yüksek olduğu görülmektedir. Pekel (2016, s.41) spor yöneticiliği bölümünde öğrenim gören öğrenciler üzerinde yapmış olduğu çalısmada katıllımciların cinsiyetlere göre üniversite yaşam kalitelerini incelemiş ve sosyal olanaklar, kararlara kattlım, öğrenci-öğrenci iletişimi, gelecek ve sınıf ortamı boyutlarında istatistiksel olarak anlamlı farklılık tespit etmemesine rağmen, öğretim elemanı-öğrenci iletişimi alt boyutunda erkek öğrenciler ve kimlik boyutunda ise kız öğrenciler yönünden istatistiksel olarak anlamlı farklılıklar görüldüğünü tespit etmiştir. Yani bu çalışmada kız öğrencilerin öğretim elemanı-öğrenci iletişiminin erkeklere oranla daha iyi olmasına rağmen Pekel (2016, s.41) çalısmasında erkek öğrencilerin kız öğrencilere nazaran öğretim elemanı-öğrenci iletişiminin daha iyi olduğunu belirtmektedir. Eriş ve Anıl (2015, s.10) çalışmalarında öğrencilerin üniversite yaşam kalitesi ortalamaları arasında cinsiyete göre anlamlı bir fark olduğu, kızların erkeklere göre üniversite yaşam kalitesini daha olumlu buldukları belirtilmektedir. Sarı, Ötünç ve Erceylan, (2007, s.313) farklı şekilde, öğrenci-öğrenci iletişiminin cinsiyetler açısından anlamlı farklılık oluşturmadığını tespit etmiştir. Ancak araştırmada kız ve erkek öğrencilerin ortalamaları arasında genel olarak ciddi farklar bulunmadığı, alanyazına ve çalışmamızla paralel şekilde de okul yaşam kalitesi algısının kız öğrenciler lehine olduğu belirtilmektedir (Majeed, Fraser ve Aldridge, 2002, s.203).

Bu çalışmada aynı zamanda cinsiyetler açısından üniversite öğrencilerinin özdeşleşme düzeylerine bakıldığında kadınların erkeklere oranla daha yüksek özdeşleşme düzeylerinin olduğu tespit edilmiştir. Özdeşleşmenin örgütsel bağlllık üzerinde olumlu yönde etki yaptığ1 (Hunt ve Morgan, 1994, s.1571; Becker, 1992, s.232; Sökmen ve Şimşek, 2016, s.606) düşünüldügünde kadınların erkeklere oranla üniversitelerine bağlllıklarının daha güçlü olduğu ifade edilebilir. Diğer yönden üniversite öğrencilerinin özdeşleşme düzeylerinin aşı11 artışının stresle başa çıkmayı ve genel ruh sağlığını olumsuz etkilediği belirtilmektedir (İkiz ve Totan, 2012, s.65). Çalışmadaki ortalama değerlerden öğrencilerin aşırı özdeşleşme düzeyleri sahip olmadıkları anlaşılmakta ve kadınların erkeklere oranla psikolojik olarak daha fazla üniversiteye uyum sağladıkları söylenebilmektedir.

Üniversitelerde gençlerin sosyalizasyon sürecinde etkili olan oluşumların başında gelen öğrenci kulüpleri/topluluklarının, öğrencilerin ders dışındaki zamanlarını kampüs içerisinde pozitif olarak kullanabilmelerindeki önemi yadsınamaz. Üniversite öğrencilerinin bir kısmının kulüplere/topluluklara üye olarak rekreasyon etkinliklerini düzenlediği, bir kısmının da sadece pasif olarak bu etkinliklere kattlım sağladığı düşünüldüğg̈nde, her üniversite yönetimin öğrenci kulüplerini/topluluklarını desteklediği ve bu tür oluşumların öğrenci ve üniversite yönetimi arasında güzel bir köprü kurduğu söylenebilir (Kilıç ve Şener, 2013, s.223-224). Araştırmada üniversitede topluluklara üye olan öğrencilerin örgütsel imaj ölçeği alt boyutlarından, spor imajı, genel görünüm ve altyapı imajının topluluklara üye olmayanlara göre daha fazla olduğu tespit edilmiştir. Bu durum özellikle üniversite topluluklarının üniversite içinde yer alan alt yapı ve tesisleri kullanarak gerçekleştirdikleri rekreatif ve sportif faaliyetler ile açıklanabilir. Öğrenci topluluklarına üye olan birçok öğrenci özellikle sportif ve rekreatif amaçlı etkinliklerden daha çok haberdar olarak bu etkinliklere hem aktif hem de pasif bir şekilde katılabilmektedir. Yine bu çalışmada kimlik, gelecek ve sınıf ortamı alt boyutlarının dışında üniversite yaşam kalitesi ve özdeşleşme düzeylerinde topluluğa üye olmanın etkisi olmadığ1 görülmüştür. Kekeç Morkoç ve Erdönmez (2018, s.520) araştırma sonuçlarına benzer şekilde topluluğa üye olma ve üniversite yaşam kalitesi boyutları arasında anlamlı farklılık bulamamışlardır. Herhangi bir topluluğa üye olan öğrenci ile olmayan öğrenci arasında üniversite yaşam kalitesi ile ilgili memnuniyet veya alg1 farklılı̆ğ bu araştırmada olduğu gibi ortaya konulamamıştır. Fakat Eriş ve Anıl (2015, s.11) öğrenci topluluğuna üye olan öğrencilerin, olmayanlara göre, üniversite yaşam kalitesinin daha olumlu olduğunu ortaya koymuşlardır. Bu durumu herhangi bir öğrenci topluluğuna üye olan öğrencilerin, daha 
fazla öğrenci ile iletişime geçmesi ve daha fazla sosyalleşebilmesi ile açıkladıkları görülmektedir. Üniversitelerin öğrencilerin beklentilerine cevap verebilmesi ve öğrencilerin yaşam kalitelerinin arttırılmasına çaba harcaması gerekmektedir. Çünkü yaşam kalitesinin arttırılması ile verim, kalite ve memnuniyet düzeyi doğru oranda artacaktır (Kekeç Morkoç ve Erdönmez, 2018, s.530). Dolayısıyla araştırma sonuçları göstermektedir ki; Pamukkale Üniversitesi'nin üniversite topluluklarını daha fazla desteklemesi, öğretim elemanları aracilğıyla topluluklara üyeliklerin öneminin daha fazla vurgulanması, öğrencilerin eğitim gördükleri alanlar dışında farklı alanlarla ilgili topluluklara üyeliğinin özendirilmesi ve Sağlık Kültür ve Spor Daire Başkanlığı vasıtasıyla topluluklara da öğrencilere erişimde daha hızlı ve kolay iletişim olanaklarını sağlaması gerektiği belirtilebilir.

Spor yapan öğrencilerin imaj algılarının yaşam kalitesi alt boyutlarından öğretim elemanı-öğrenci iletişimi, sosyal olanak, öğrenci-öğrenci iletişimi ve gelecek alt boyutlanında spor yapmayanlardan yüksek olduğu bulunmuştur. Sadece kimlik alt boyutunda spor yapmayanların spor yapanlara göre daha yüksek yaşam kalitesi algısına sahip oldukları görülmüştür. Sirgy, Grzeskowiak ve Rahtz (2007, s.349) çalışmalarında öğrencilerin üniversitedeki spor ve rekreatif aktivitelerine katılım düzeylerinin yaşam kalitesi algisıyla olumlu bir ilişkisi olduğunu ifade ettikleri görülmektedir. Yaran vd., (2017, s.73) çalışmalarında spor yapan üniversite öğrencilerin spor yapmayan üniversite öğrencilerine göre yaşam kalitesinin daha iyi bulunduğu görülmüş ve üniversite öğrencilerinde sporun teşvik edilmesinin gelecekte oluşturacakları yaşam tarzı için önemli olduğu belirtilmiştir. Araştırma sonuçları da dikkate alındığında hem öğrenciöğrenci hem de öğretim elemanı-öğrenci iletişimde ve sosyal olanak alt boyutlarında spor yapan öğrencilerin daha yüksek skorlara sahip olması özellikle sosyalleşme anlamında da sporun üniversite öğrencileri üzerinde etkisini göstermektedir.

Üniversite imaj ölçeğinden, özdeşleme düzeyi üzerinde en güçlü etkisi olan imaj, kalite imajı $(\beta=.419$, $\mathrm{p}<.01)$ olmuştur. Üniversitenin katıllımcılar tarafından kalitesi yüksek bir kurum olarak değerlendirildiği görülmektedir. Bu durumun da öğrencilerin üniversite ile özdeşleşme düzeylerini olumlu yönde etkilediği ifade edilebilir. Argon ve İsmetoğlu (2016, s.241) eğitim kurumlarının öğrencilerini destekleyici tutum ve davranış içerisinde olması ile okula devam, ders içi ve dışı aktivitelere aktif katılımın, öğrencinin kendisini toplumun saygın bir üyesi olma inancını pekiştirmesine katkı sağlayacağını belirtmektedir. Araştırmada görüldüğü üzere üniversite öğrencilerinin algıladıkları üniversite imajı üniversite özdeşleşme düzeyini olumlu yönde etkilemiştir. Dukerich, Golden ve Shortell de (2002, s.512), iş görenler açısından baktıkları çalışmalarında olumlu imaj algısına sahip iş görenlerin çalıştıları örgüte karşı daha fazla örgütsel özdeşleşme hissettiklerini ortaya koymuşlardır. Dolayısıyla araştırma sonuçlarını destekler nitelikte, öğrencilerin üniversiteye karşı algıladıkları imajı olumlu yönde etkilemenin öğrencilerin üniversiteye özdeşleşmelerine katkı sağlayacağı düşünülmektedir.

Üniversite yaşam kalitesinin özdeşleme düzeyi üzerinde en güçlü etkisi, öğretim elemanı-öğrenci iletişimi $(\beta=.248, \mathrm{p}<.01)$ alt boyutunda görülmektedir. Yine üniversite yaşam kalitesinin kalite imaj algis1 üzerinde en güçlü etkisi, öğretim elemanı-öğrenci iletişimi $(\beta=.308, \mathrm{p}<.01)$ alt boyutunda görüldüğü ortaya çıkmıştır. Araştırma sonuçlarında görüldüğü gibi öğretim elemanı-öğrenci iletişimi eğitimde verimlilikten bahsedilmesi ve üniversitenin dışardan nasıl bir imaja sahip olduğunun açıklanması bakımından önemli bir konudur. Çünkü öğrencilerin öğretim elemanlarından memnuniyeti, eğitim hedeflerinin öğrenciler tarafindan kabul edilmesi, okul uygulamalarının öğrencilerce algilanması gibi konularda önemli bir unsur olarak değerlendirilmektedir (Çokluk Bökeoğlu ve Yılmaz, 2007, s.188). Dolayısıyla öğretim elemanlarının aslında öğrenciler için birer rol model olarak da görev ve sorumlulukları olduğu düşünüldüğünde bu araştırmada da öğretim elemanı-öğrenci iletişiminin öğrencilerin özdeşleşme düzeylerini en güçlü etkileyen alt boyut olarak çımasında etkili olduğu belirtilebilir.

Araştırma sonuçlarına göre ilişkin kurulan regresyon analiz modelinde; üniversite yaşam kalitesinin program imaj1, spor imaj algıs1, genel görünüm, eğlence ve barınma ve beslenme üzerinde en güçlü etkisi gelecek alt boyutunda olduğu ortaya çıkmıştır. Özellikle gelecek alt boyutu üzerinde güçlü etkisi olduğu düşünüldüğünde öğretim elemanlarının öğrencilerini vizyoner bakış açısı ile geleceğe hazırlamalarının gerekliliğinden söz edilebilir. Örneğin akademik hedefleri olan başarılı bir öğrenci bu doğrultuda yönlendirilebilir. Sevilmiş ve Şirin (2016, s.39) üniversite öğrencilerinin akademik güdülenme ve akademik öz yeterlik konularını içeren öğretim elemanlarına yönelik bilgilendirici toplantılar ve seminer çalısmaları düzenlenmesinin yararlı olabileceğini belirtmişlerdir. Ayrıca üniversite yaşam kalitesinin sosyal ortam imaj1 üzerinde en güçlü etkisi, öğretim elemanı-öğrenci iletişimi alt boyutunda olduğu görülmüştür. Bu da öğretim elemanları ile öğrenci iletişiminin üniversite yaşam kalitesinin belirleyici unsurlarından olduğunu göstermektedir. Öğrencilerin fakülte ve bölümle bütünleşme sürecinde öğrenci- öğretim elemanı arasındaki 
iletişimin, öğrencilerin bölümlerinin vizyon, misyon ve eğitim hedefleri konusundaki algılarını değiştirdiği belirtilmektedir (Çerik ve Erkmen, 2006, s.19). Özellikle örgütün kültürüyle ilişkili olan öğrenci-öğrenci ve öğretim eleman1-öğrenci iletişiminin imaj için önemli bir unsur olduğu görülmektedir.

Üniversitelerde eğitim gören öğrenciler ülkelerinin geleceğini şekillendirecek olan bireylerdir. Üniversite öğrencilerinin üniversite eğitimleri boyunca üniversite içerisinde yaşayacakları deneyimler, tecrübeler, alacakları eğitim vb. olanaklar kendilerini gerçekleştirebilmelerine ve gelişimlerine katkı sağlayacaktır. Aynı zamanda bu durum üniversite öğrencilerinin eğitim gördükleri üniversiteler için de alg1ladıkları imajı, üniversite yaşam kalitesi ve özdeşleşme düzeylerinin de belirleyicisi olmaktadır. Sonuç olarak, bu araştırmada da yaşam kalitesi, üniversite imajını ve özdeşleşme düzeyini etkilerken; imaj algısının ayrıca özdeşleşme düzeyinde de etkisi olduğu ve PAÜ yaşam kalitesinin öğrencilerin üniversite imajını algılama biçimlerini ve özdeşleşme düzeylerini pozitif yönde etkilediği görülmüştür. Bu noktada üniversitelerin üniversite öğrencilerine odaklı projeler ve faaliyetler gerçekleştirmeleri gerekmektedir. Özellikle sosyal ve sportif imkânların arttırılması, eğitim ve öğretimden memnuniyet duyulması, öğrenciler arasında kaynaşmanın arttırılması ve öğretim elemanları ile öğrenci etkileşiminin güçlü olması üniversitelerin yaşam kalitesi için önemli olduğu ifade edilebilir. Üniversite öğrencilerinin üniversitelerine karşı güçlü imaj algılarına sahip olmalarının da üniversite ile özdeşleşme düzeylerine olumlu etki yaptı̆̆1 söylenebilir. Bu araştırma sonuçlarına göre bundan sonra yapılacak araştırmaların farklı üniversiteleri kapsayacak şekilde örneklem grubu genişletilerek yapılması ve farklı değişkenlerin karşıaştırılması ya da ilişkilendirilmesinin yapılması önerilebilir. Böylece sonuçların tek bir üniversite değil birden fazla üniversite ile genellenebilirliği arttır1labilir.

\section{Etik Beyan}

"Pamukkale Üniversitesi Öğrencilerinin Yaşam Kalitesi, Örgütsel İmaj ve Özdeșleșme Düzeyleri Arasındaki İliskilerin Incelenmesi" başılılı çalışmanın yazım sürecinde bilimsel, etik ve alıntı kurallarına uyulmuş; toplanan veriler üzerinde herhangi bir tahrifat yapılmamış ve bu çalışma herhangi başka bir akademik yayın ortamına değerlendirme için gönderilmemiştir.

\section{Not}

Bu çalışma 15-18 Kasım 2017 tarihleri arasında Antalya'da düzenlenen 15. Uluslararası Spor Bilimleri Kongresi’nde sözel bildiri olarak sunulmuş ve ilgili kongrenin özet kitabında yayınlanmıştır.

\section{Kaynakça}

Ashforth, B. E. ve Mael, F. (1989). Social identity theory and the organization. The Academy of Management Review, 14(1), 20-39.

Becker, T. E. (1992). Foci and bases of commitment: Are they distinctions worth making?, Academy of Management Journal, 35-1, 232-244.

Büyüköztürk, Ş. (2016). Sosyal bilimler için veri analiz̨i el kitabı (22. Baskı). Ankara: Pegem Akademi.

Büyüköztürk, Ş., Kilıç Çakmak, E., Akgün, Ö. E., Karadeniz, Ş. ve Demirel, F. (2019). Eğitimde bilimsel araştrma yöntemleri (26. Baskı) Ankara: Pegem Akademi.

Can, A. (2014). SPSS ile bilimsel araştrma sürecinde nicel veri analir̨i. (Üçüncü Baskı). Ankara: Pegem Akademi.

Cerit, Y. (2006). Eğitim fakültesi öğrencilerinin üniversitenin örgütsel imaj düzeyine ilişkin algıları, kuram ve uygulamada eğitim yönetimi. Educational Administration: Theory and Practice, 47, 343-365.

Çatt, K., İştar, E., ve Özcan, H. (2016). Üniversite tercihlerine etki eden faktörlerin incelenmesi: Türkiye genelinde bir alan araştırması. Yüksekögretim ve Bilim Dergisi, 6(2), 163-177.

Çerik Ş. ve Erkmen T. (2006). Kurum imajını etkileyen faktörlerin algilanması ve bu algilamaların beklentilerle karşılaştırılması: Üniversite öğrencilerine yönelik bir araştırma. Mustafa Kemal Üniversitesi Sosyal Bilimler Enstitiusü Dergisi, 3, 6. 1-22.

Çokluk Bökeoğlu, Ö. ve Yllmaz, K. (2007). Üniversite öğrencilerinin fakülte yaşamının niteliğine ilişkin görüşlerinin çeşitli değişkenler açısından incelenmesi. Ankara Üniversitesi Eğitim Bilimleri Fakülltesi Dergisi, 40(2), 179-204.

Doğanay, A. ve Sarı M. (2006). Öğrencilerin üniversitedeki yaşam kalitesine ilişkin algıılarının demokratik yaşam kültürü çerçevesinde değerlendirilmesi (Çukurova üniversitesi örneği). Türk. Ë̆itim Bilimleri Dergisi, 4(16), 107128.

Dukerich, J. M., Golden, B. R. ve Shortell, S. M. (2002). Beauty is in the eye of the beholder: the impact of organisational identification, identity, and image on the cooperative behaviors of physicians. Administrative Science Quarterly, 47, 507-533.

Dutton, J. ve Dukerich, J. (1991). Keeping an eye on the mirror: image and identity in organizational adaptation. Academy of Management Review, 34, 517-54.

Eriş, H. M. ve Anıl, D. (2015). Üniversite öğrencilerinin yaşam kalitesi düzeylerinin bazı değişkenlere göre incelenmesi. Hacettepe Üniversitesi Ë̈itim Fakültesi Dergisi, DOI:10.16986/HUJE.2015014183, 1-14. 
Hunt, S. D. ve Morgan R. M. (1994). Organizational commitment: one of many commitment or key mediating construct, Academy of Management Journal, 37(6), 1568-1587.

İkiz, E. ve Totan, T. (2012) Üniversite öğrencilerinde öz-duyarlık ve duygusal zekânın incelenmesi. Dokuz Eylül Üniversitesi Sosyal Bilimler Enstitüsü Dergisi, 14(1), 51-71.

İşcan, Ö. F. (2006). Dönüştürücü/etkileşimci liderlik alg1sı ve örgütsel özdeşleşme ilişkisinde bireysel farklılıkların rolü. Akdeniz Üniversitesi İktisadi ve İdari Bilimler Fakültesi Dergisi, 11, 160-177.

Karabey, C. N. ve İşcan, Ö. F. (2007). Örgütsel özdeşleşme, örgütsel imaj ve örgütsel vatandaşlık davranışı ilişkisi: bir uygulama. Atatürk Üniversitesi İktisadi ve İdari Bilimler Dergisi, 21(2), 231-241.

Karacabey, M. F., Özdere M. ve Bozkuş, K. (2016). Üniversite öğrencilerinin örgütsel imaj alg1ları. Akademik Sosyal Arasttrmalar Dergisi, 4(33), 459-473.

Kazoleas, D., Kim Y. ve Moffitt, M. A. (2001). Institutional image: A Case Study. Corporate Communications, 6(4), 205216.

Kekeç Mokaç, D. ve Erdönmez, C. (2018). Yükseköğretim öğrencilerinin yaşam kalitesine yönelik algıları: Çanakkale onsekiz mart üniversitesi örneği. Yönetim Bilimleri Dergisi, 16(32), 509-532.

Kılıç, M. ve Şener, G. (2013) Üniversite öğrencilerinin rekreasyon etkinliklerine katıllımlarındaki sosyolojik etkenler ve yapisal k1sitlamalar. Yükesekögretim ve Bilim Dergisi, 3(3), 220-227, DOI: 10.5961/jhes.2013.08.

Levinson, H. (1965), Reciprocration: The relationship between man and organization, Administrative Science Quarterly, $9-4$.

Mael, F. A. ve Ashforth, B. E. (1992). Alumni and their alma mater: a partial test of the reformulated model of organizational identification. Journal of Organizational Behaviour, 13(2), 103-123.

Majeed, A., Fraser, B. J. ve Aldridge, J. M. (2002). Learning environment and its association with students satisfaction among mathematics students in Brunei Darussalam. Learning Environments Research, 5, 203-226.

Moller, V. (1996). Life satisfaction and expectations for the future in sample of university students: A research note. South African Journal of Sociology, 27(1), 109-125.

Okay, A. (2000). Kurum Kimliği. Ankara: MediaCat Yayınları.

Pekel, A. (2016) Spor yöneticiliği bölümünde öğrenim gören ögrencilerinin akademik öz yeterlilikleri ve üniversite yaşam kalitesi arasindaki ilişkinin incelenmesi. Erciyes Üniversitesi Sağllk Bilimleri Enstitüsü, Kayseri.

Polat, S. (2011). Üniversite öğrencilerine göre Kocaeli Üniversitesi’nin örgütsel imaj1, Eğitim ve Bilim Dergisi, 36(160), 105-119.

Polat, S. (2011). Üniversite öğrencilerinin örgütsel imaj algıları ile akademik başarıları arasındaki ilişki düzeyi. Kuram ve Uygulamada Ë̆itim Bilimleri, 11(1), 249-262.

Sarı, M., Ötünç, E. ve Erceylan, H. (2007). Liselerde okul yaşam kalitesi: adana ili örneği. Kuram ve Uygulamada Ĕ̈itim Yönetimi, 50, 297-320.

Sevilmiş, A. ve Şirin E. F. (2016). Spor bilimleri fakültesi öğrencilerinde akademik başarı: üniversite yaşam kalitesi, akademik güdülenme ve akademik öz yeterliğinin rolü. Ankara Üniversitesi Spor Bilimleri Fakültesi Dergisi, 14(1), 31-44.

Sirgy, M. J., Grzeskowiak, S. ve Rahtz, D. (2007). Quality of college life (QCL) of students: Developing and validating a measure of well being. Social Indicators Research, 80(2), 343-360.

Sökmen, A. ve Şimşek, T. (2016). Örgütsel bağlllık, örgütle özdeşleşme, stres ve işten ayrılma niyeti ilişkisi: Bir kamu kurumunda araştırma. Gażi Üniversitesi İktisadi ve İdari Bilimler Fakültesi Dergisi, 18(3), 606-620.

Tak, B. ve Aydemir B. A. (2004). Örgütsel özdeşleşme üzerine iki görgül çalışma, 12.Ulusal Yönetim ve Organiz̧asyon Kongresi Bildiri Kitabı, 27-29 May1s 2004, 59-63.

Wilson, A. (2001). Corporate reputation: seeking a definition. Corporate Communication An International Journal, 6(1), $24-$ 30.

Yaran, M., Ağaoğlu, S. A. ve Tural, E. (2017). Spor alışkanlı̆̆1 olan ve olmayan üniversite öğrencilerinde uyku ve yaşam kalitesinin incelenmesi. Ergoterapi ve Rehabilitasyon Dergisi, 5-2, 73-78.

\section{EXTENDED ABSTRACT}

Education is an important subject which continues throughout the lives of individuals and shapes the future of the country. Therefore, the quality of the education provided by the institutions is extremely important (Eriş and Anıl, 2015). As the content of the educational, physical and social opportunities of a university become more diverse and richer, the satisfaction of the students from the university environment would be higher. The satisfaction students get from the environment they are in, positively affects their academic achievement, satisfaction with life, social relationships and indirectly their future life (Moller, 1996). Furthermore, the education and opportunities that universities offer help individuals to increase their quality of life. It is a known fact that increasing the students' quality of life, contributes to getting better results in education (Eriş and Anil, 2015). Universities constantly require to strengthen their organizational image positively toward public opinion. Organizational image is the attitudes and evaluations that develop in the minds of the individuals (employees, clients, students, instructors, etc.) that are affected by the institution about the organization. The depth of organizational identification which is defined as belonging to the organization and liaising (Ashforth and Mael, 1989), is determined by the self- 
perception of the individual (Karabey and İşcan, 2007). It is a fact that the effect of services and conditions that are provided by the university to the students who are the stakeholders of universities is an important factor for students to feel as a part of their university. Accordingly, in this research, it was aimed to examine the relationships between Pamukkale University students' the quality of life, organizational image, and level of identification.

The study was conducted within the scope of (instantaneous) survey researches. The study consists of a total of 1506 students, 583 females (37.7\%) and 923 males (61.3\%), which were chosen by cluster sampling method among 55.800 students who are studying in the spring semester of 2016-2017 academic year in the 16 faculties, 12 vocational schools of higher education and 3 colleges of Pamukkale University. $61.2 \%$ of the students were studying in faculties (n:922), $19.3 \%$ of them were studying in vocational schools of higher education (n:291) and 19.5\% of them were studying in colleges. While $35 \%$ of the students were a member of a community in the university, $65 \%$ of them weren't. Furthermore, while $23.4 \%$ of the students were actively performing exercise, $76.6 \%$ of them weren't performing any exercise. In the study, personal information form which was developed by the researcher was used. Quality of Life in University Scale which was developed by Doğanay and Sar1 (2006) for Kocaeli University (KOU) sample was used by changing the KOU statements into PAU (Pamukkale University) from the items in the scale. However, no other change was performed apart from this alteration by abiding the content of the items. Perceived Organizational Image Scale, which was developed by Kazoleas, Kim and Moffitt (2001) and adapted by Polat (2011) and Organizational Identification Scale, which was developed by Mael and Ashforth (1992) and adapted by Tak and Aydemir (2004) were used. The obtained data were analyzed with discrepancy and relationship analyses. For the determination of differences between the variables, independent samples t-test and for the determination of the relationships, correlation and regression analyzes were conducted in SPSS 20 program.

According to the findings of this study which was conducted in order to examine the relationship between Pamukkale University students' the quality of life, organizational image and level of identification, it was observed that the image perception of females are higher than males in the quality, program, sports, general view and infrastructure, social environment, accommodation-nutrition subdimensions of organizational image scale, when evaluated in terms of gender. When the quality of life in university is examined in terms of genders, it was observed that females' quality of life were again higher than males in instructor-student communication, agreeing with the decisions, student-student communication, future, and class environment sub-dimensions. When identification levels of university students were examined in terms of gender, it was determined that females had a higher identification level than males. It was determined that the image perception of students who are a member of communities in the university were higher than students who are not a member of any community in the sports image, general view and infrastructure image sub-dimensions of organizational image scale. It was observed that being a member of a community did not have any effect on the quality of life in university and identification levels, except for identity, future and class environment sub-dimensions. The image perceptions of students who performed exercise were higher than students who didn't perform exercise in instructor-student communication, social opportunity, student-student communication and future subdimensions of quality of life scale. It was observed that students who didn't perform exercise had a higher quality of life perception than those who perform exercise only in identity sub-dimension. Image, quality image had the strongest effect on the level of identification $(\beta=.399, \mathrm{p}<.01)$ in Perceived Organizational Image Scale. It was observed that the university was perceived as a quality institution by the participants. This situation positively affects the students' level of identification with the university. The strongest effect of the life of quality in university on the level of identification was observed in the instructorstudent communication $(\beta=.214, \mathrm{p}<.01)$ sub-dimension. It was also revealed that the strongest effect of the life of quality on quality image perception was observed in instructor-student communication $(\beta=.346$, $\mathrm{p}<.01)$ sub-dimension. As it can be seen in the results of the research, instructor-student communication is an important subject in terms of mentioning efficiency in education and explaining what kind of an image does the university possess. Because the satisfaction of students from instructors is evaluated as an important factor in subjects such as acknowledging the education objectives by the students and perceiving the university practices by the students (Çokluk Bökeoğlu and Yılmaz, 2007). While a medium and weak, positive and significant relationship was determined between all of the sub-dimensions of scales, a weak, negative and significant relationship was determined only between the identity subdimension of quality of life with all of the sub-dimensions of image perception and identification scale. In the regression analysis method which was created in accordance with the results of the research, it was 
revealed that the strongest effect of the life of quality was on future sub-dimension among the program image, sports image perception, general view, entertainment, and accommodation-nutrition subdimensions.

While the life of quality affects the university image and level of identification, it was observed that the image perception had an effect on the level of identification. Furthermore, it was observed that the strongest effect of quality of life in university scale on social environment image was on instructorstudent communication sub-dimension. As a result, it was observed that PAU life of quality, positively affected the way of perceiving university image by the students and the level of identification. 